\title{
العُرف: دراسة أصولية اجتماعية
}

\section{يونس صوالحي \\ غالية بوهدة}

\begin{abstract}
الملخص

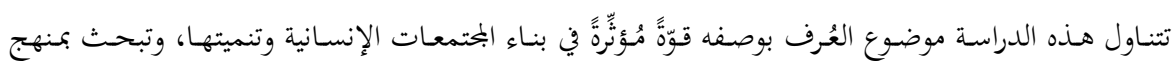

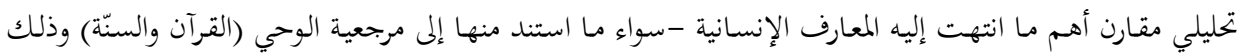

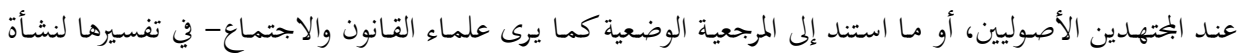

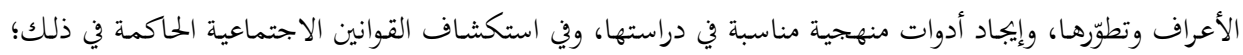
لغرض تسخيرها في تنمية المختمعات على نخوِ تتكامل فيه بين حاجاتها المادية ومتطلّباها الروحية.

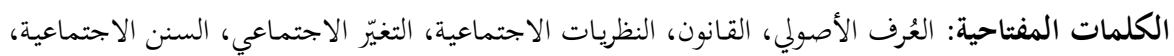
وسائل سسيومترية.

\section{Custom: A Socio-Usuli study}

\section{Abstract}

This study addresses the concept of custom as an influential factor in building and developing human societies. Using comparative-analytical research methods, it examines both revealed knowledge (Qur'an and Sunnah) of Muslim Usuli jurists and positivistic knowledge propagated by contemporary scholars of law and sociology in relation to the emergence and development of customs. It also aims at finding methodological instruments, and discovering the governing social laws necessary to develop societies both physically and spiritually.

Key words: Usuli custom, Law, Social theories, Social change, Social laws, Sociometric methods.

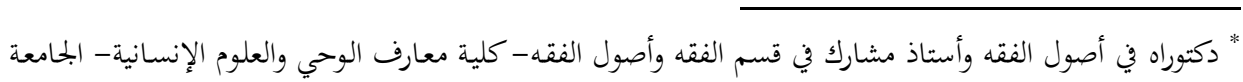

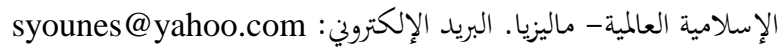

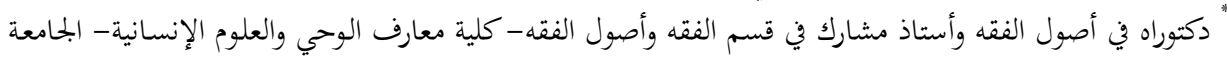

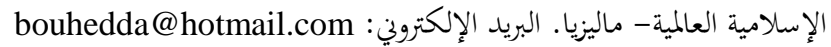

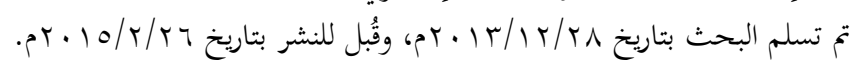




\section{مقدمة:}

يتبوأ العُرف مكانةً راسخةً في التشريعين: الإسـلامي، والوضعي؛ نظراً لمراعاته مبدأ الواقعية فيهما، وتقرير متطلّبات الحياة الفطرية اللازمة لقيام اجتماع بني البشر، التي تتمثّل

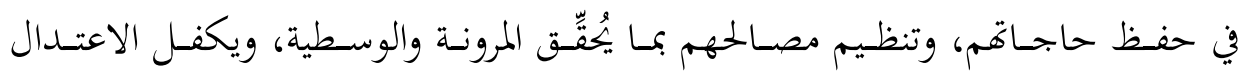
والعدل بينهم في مختلف شؤون الحياة، وئ ما يطمحون إليه من الرُّقي والرّقَعة.

يجظى العُرف أيضـاً باهتمـام بـارز في الدراسـات الاجتماعيـة الستي تعنى بتحليـل الظواهر الاجتماعيـة مـن أجل التنميـة، وتحسـين الأداء السوسيولوجي للمجتمع في جميع

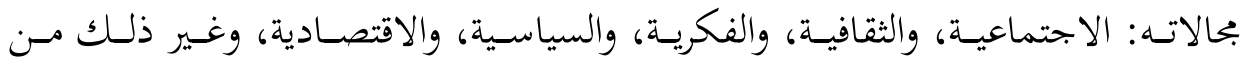

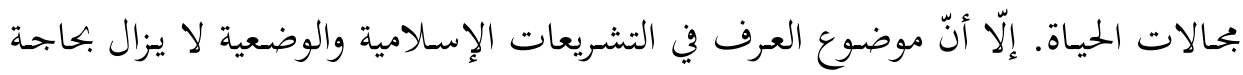

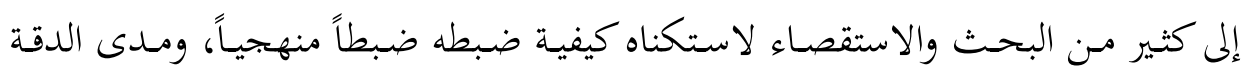
العلمية في بيان ثبوته وبجالاته، ورسم حدوده وضوابطه.

ولا يخفى على أحد ما تشهده العلوم الاجتماعية في هذا العصر من تطوّر في طرق

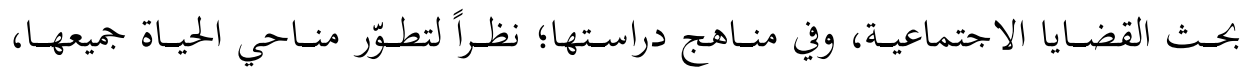

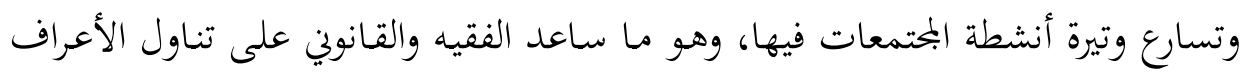

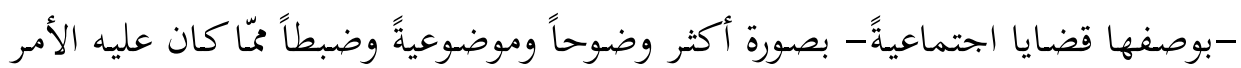

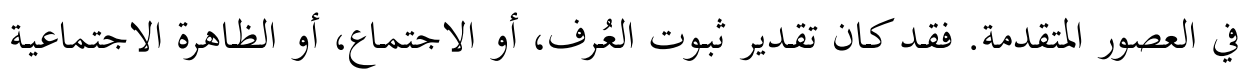

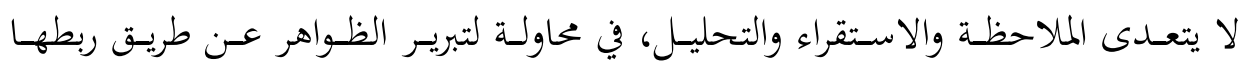

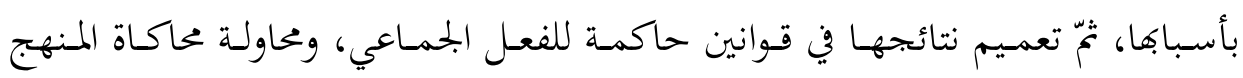
التجريبي في ذلك.

ولكنّ هيمنة نزعة الأنا على فكر الباحث الاجتماعي، وعلى منطلقاته الشخصية

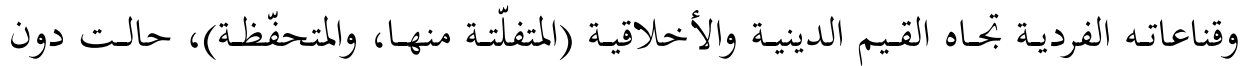

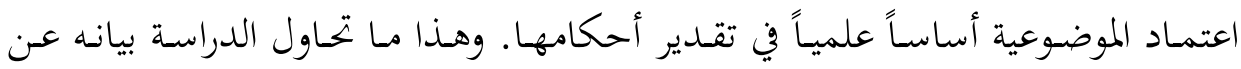
طريق استعراض نظرة أهم النظريات السوسيولوجية الغربية إلى الفعل الاجتماعي؛ منهجاً، 
ولمّا كان العُرف مصدراً من مصادر التشريع والقانون بالشروط التي حدّدها فقهاء التشريع الإسلامي والوضعي، فيإنّ من المفيد محاولة البحثث في إمكانية استخدام مناهج

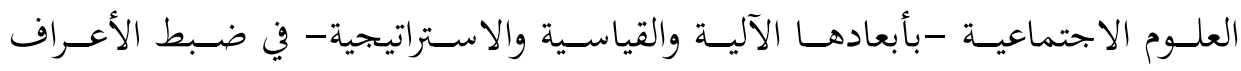

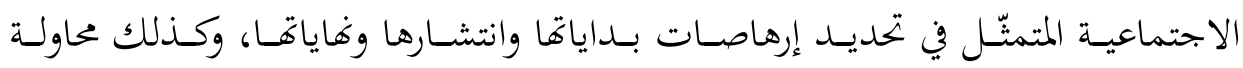

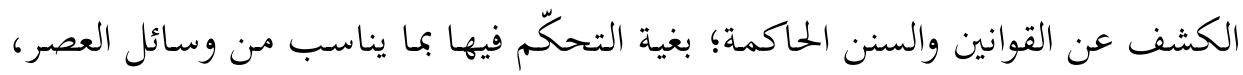

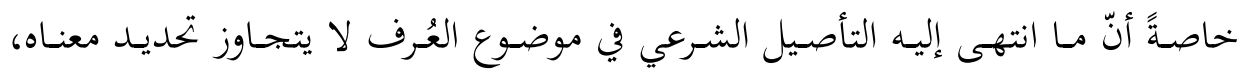
وأركانه، وشروطه، وأنواعه، وتقسيماته (عام، خاص)، وحجيته عند الأصوليين والفقهاء.

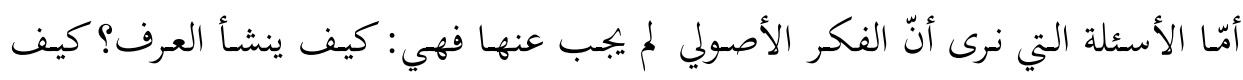

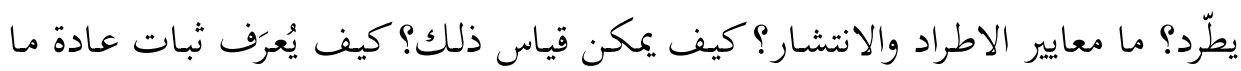

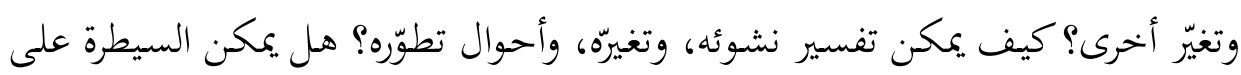

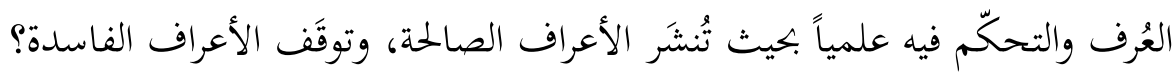
تمدف هذه الدراسة إلى محاولة بيان السنن الاجتماعية التي يقوم عليها اعتبار العرف

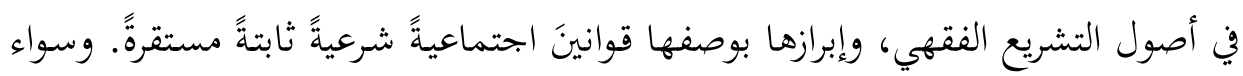

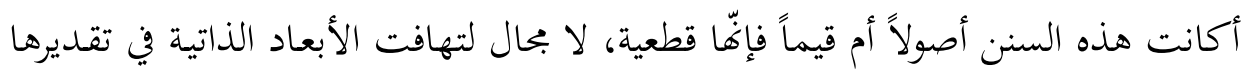

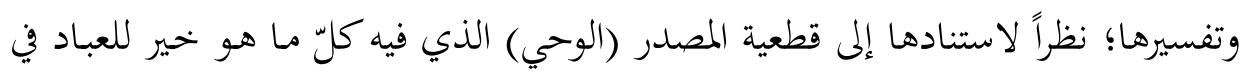
الدنيا والآخرة.

تحاول هذه الدراسـة الإجابة عن الأسئلة الآنف ذكرها، على نحوِ يجمع بين البُعْد

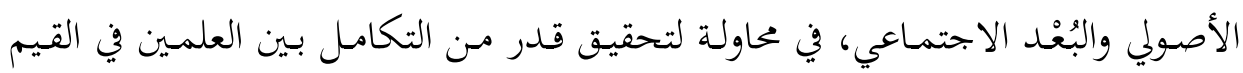
والمناهج

\section{أولاً: العُرف الأصولي وواقعية التشريع الإسلامي}

العُرف لغةً يعني التتابع والمألوف من الأفعال والأقوال. 'أمّا اصطلاحاً فهو ما استقر في النفوس مـن قول أو فعل، وتلقّتـه الطبـاع السـليمة بـالقبول. بُ وقـد خـاض الأصـوليون

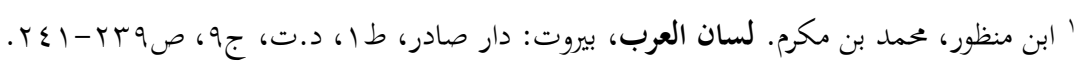

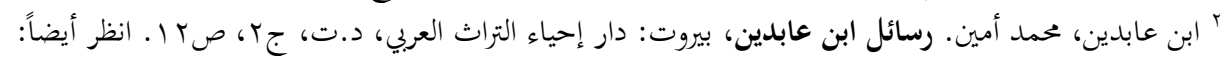


والفقهاء في علاقة العرف `بالعادة، و واختلفوا في مسألة اختصاص العادة بالعرف القولي دون العرف العملي. لكنّ المحقّين وجدوا أنّ الفقهاء قد أجروا العادة في الأقوال والأفعال

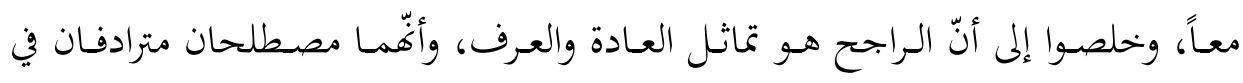

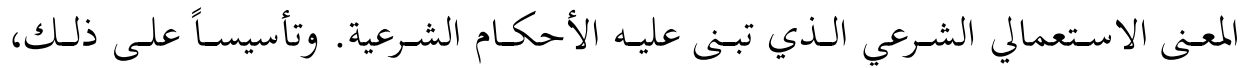

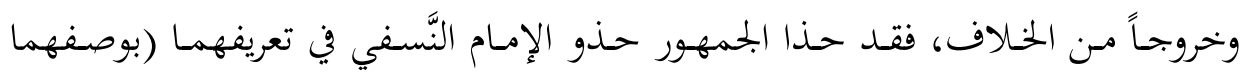

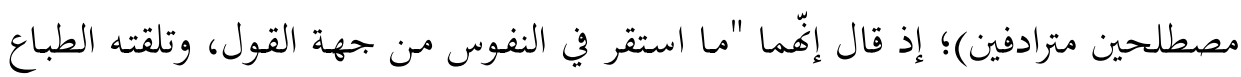

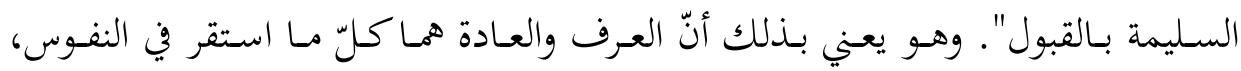

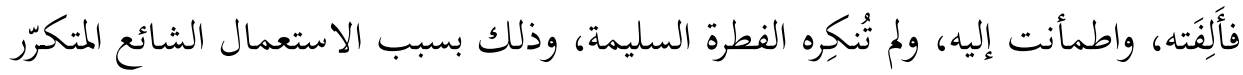

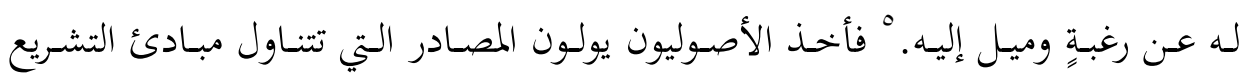

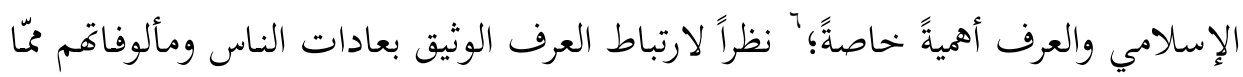
يشتركون في الحاجة إليه من المصالح لحربه وقد أقرّ التشريع الإسلامي كثيراً من عادات الناس قبل الإسلام وبعده لحكمةٍ كان

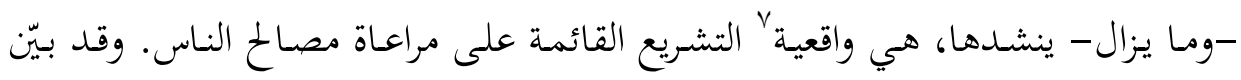
ذلك ابن قيّم الجوزية في قوله: "إن الشريعة مبناها وأساسها على الحكم ومصالح العباد في مئي

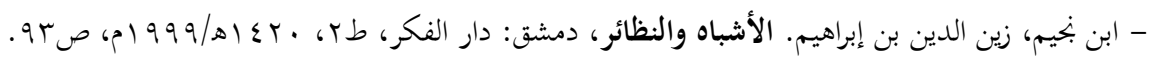

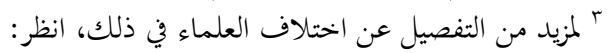

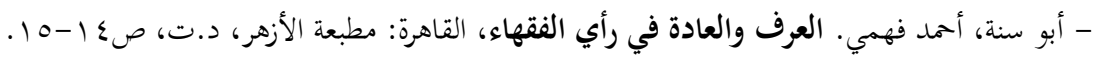

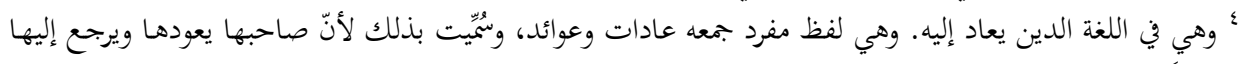
مرّةً بعد مرّة. انظر: في الفة الدين بعاد

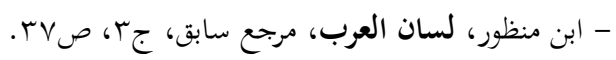

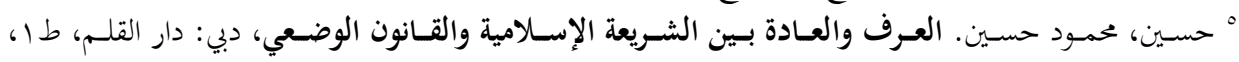

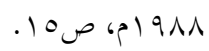

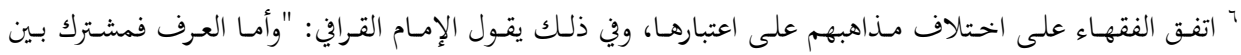

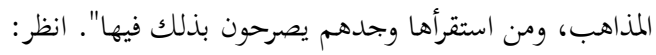

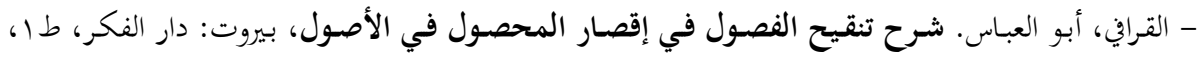
r $99 \mathrm{~V}$

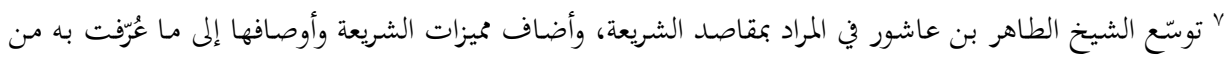

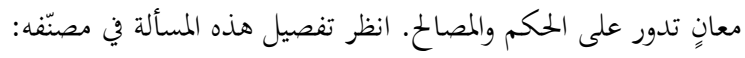

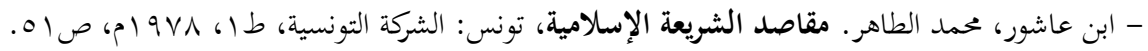


المعاش والمعاد، وهي عدل كلها، ورحمة كلها، ومصالح كلها، وحكمة كلها، فكل مسألة

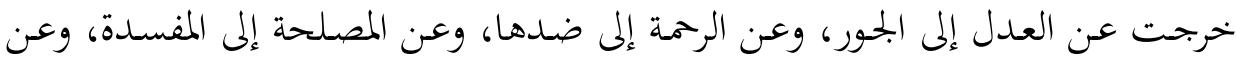

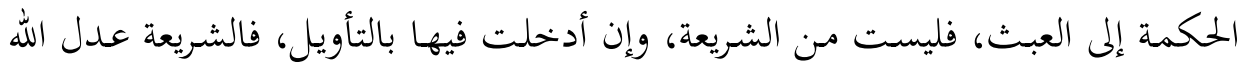
بين عباده، ورمته بين خلقه، وظله في أرضه، وحكمته الدالة عليه وعلى صدق رسوله فئس

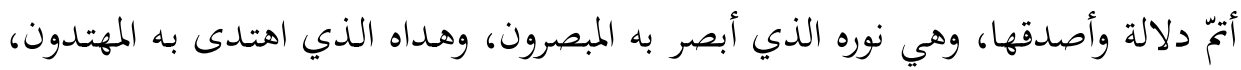
وشفاؤه التام الذي به دواء كل عليل، وطريقه المستقيم الذي من استقام عليه فقد استد استقام

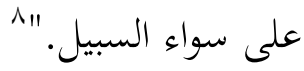

ويشهد تاريخ التشريع على تشكّل أعراف عرضت نفسها على التشريعات القائمة

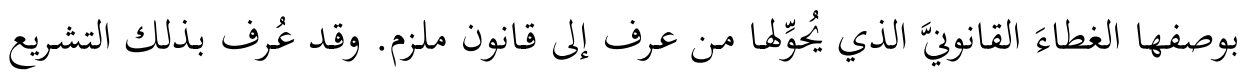

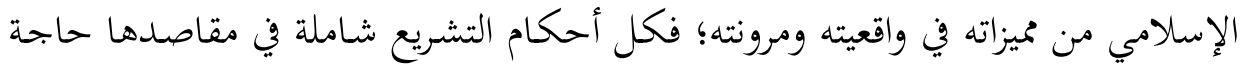

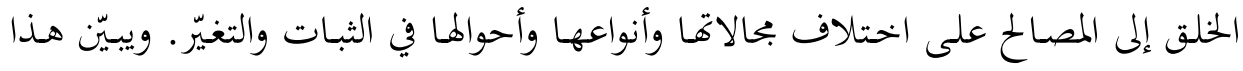

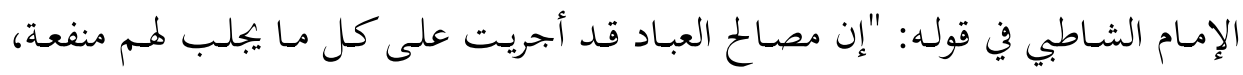

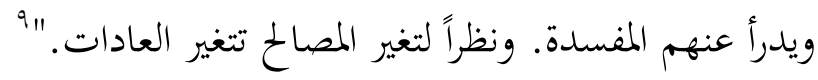

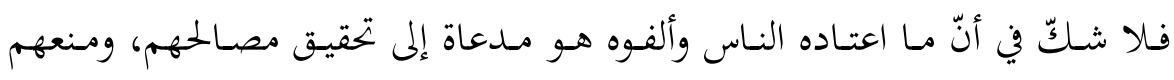

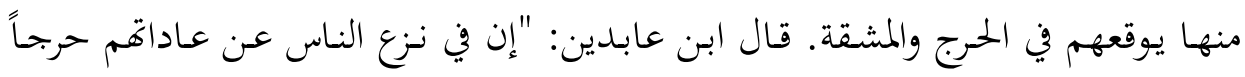

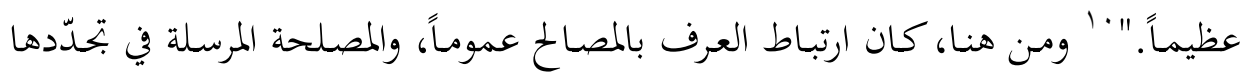

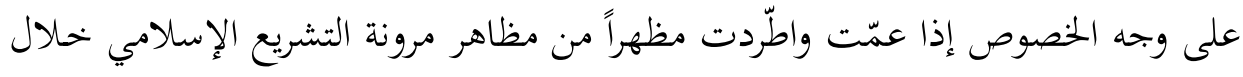

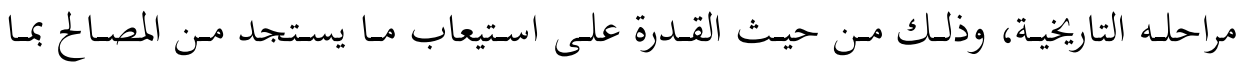

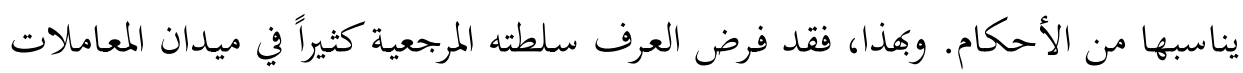

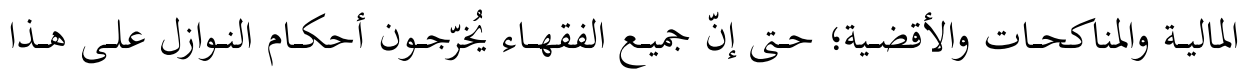

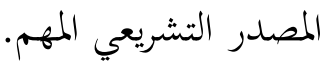

^ ابن القيّم، حمد بن أبي بكر. إعلام الموقعين عن رب العالمين، بيروت: المكتبة العصرية، ط1، 9 ( (م) ج)،

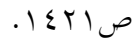

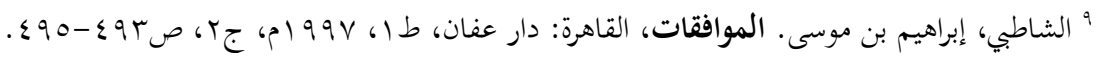

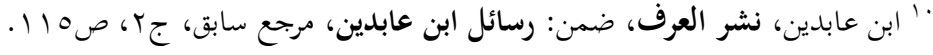


وقد فصّل في هذا الاستدلال الإمام الشاطبي لما بيّن أن الشارع الحكيم قد اعتبر

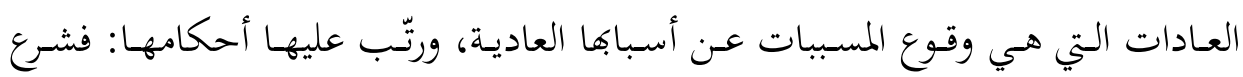

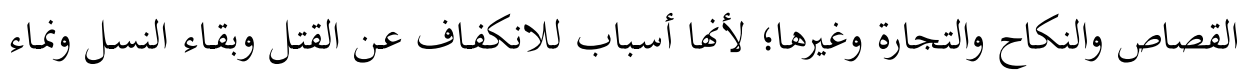

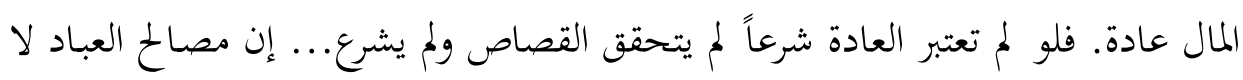

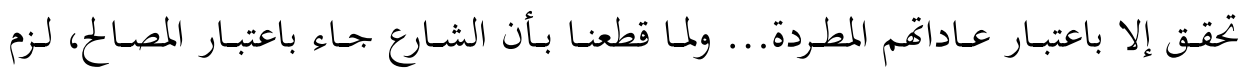

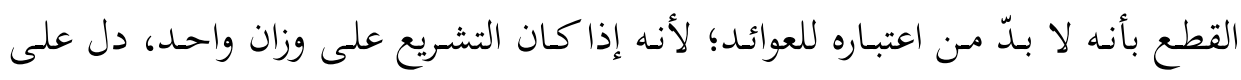

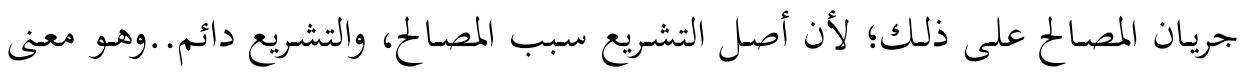

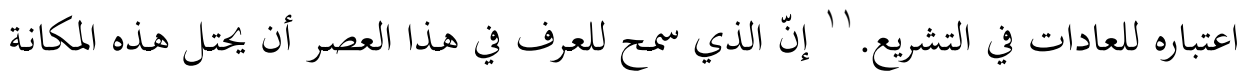

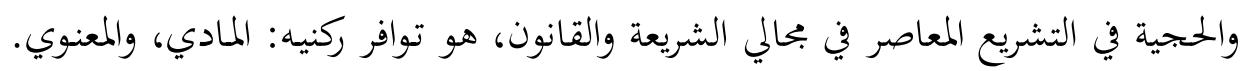

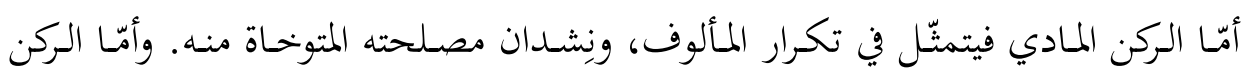

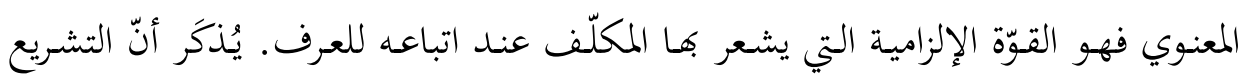

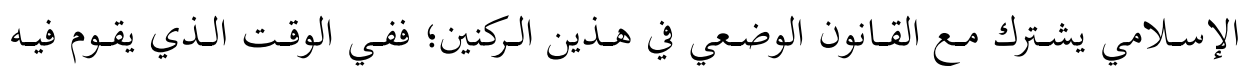

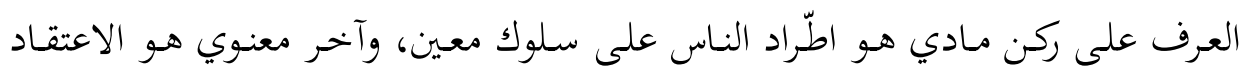

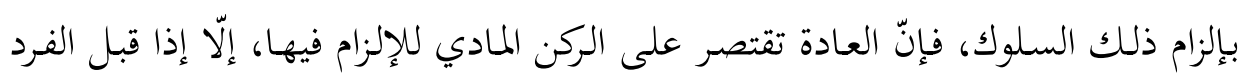
اتباعها بمحض إرادته، فيما يُسمّى في عرف القانون "العادة الاتفاقية". والأمر في أصول الفقه قد يختلف عنه في القانون الوضعي. فالقانون هو الذي يُنشئ

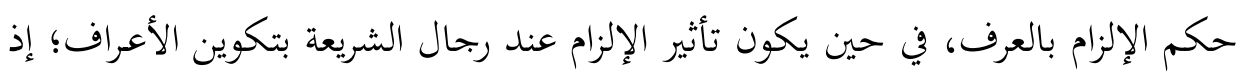

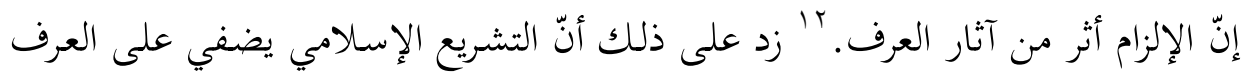

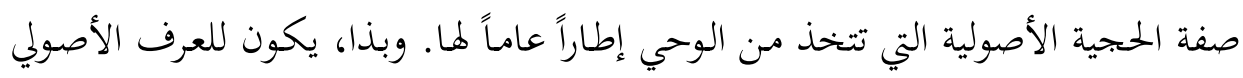
قيمة أخلاقية تنبع من التشريع الإلهي.

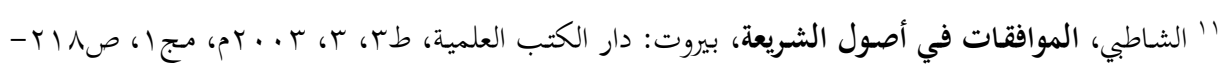


والعرف في أهميته التشريعية منوط به بيان الحكم الشرعي في النص من حيث تنزيله، وحكم مـا لا نص فيه من المستجدات من الأعراف بما يُمقِّق مقاصد الشـارع في الواقعية والمرونـة. مثـال ذلك ردّ بيـان أحكام الاخـتلاف في تقـدير النفقـة إلى العرف. قـال ابـن قدامة: "والصحيح ما ذكرناه من رد النفقة للمطلقة في الشرع إلى العرف فيما بين الناس في نفقاتم في حق الموسر والمعسر والمتوسط بما رددناهم في الكسوة إلى ذلك." وقال العز عبـد السـلام: "تنـيل دلالـة العـادات وقـرائن الأحسوال منـزلة صـيح الأقوال في تخصسيص

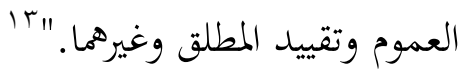

فالفقيـه في ذلك جـامع بـين مصـالح الشـارع ومصـالح الخلقق على اختلاف أنواعها وأحوالها، بحسب الإمام الشاطبي رحمه الله. وهذا متحقّق في إطار إعمال الشروط الشرعية الموضوعة لاعتبـار العرف؛ كعدم اصطدامه بالنصوص الشرعية، وضرورة اطٌّاده وانتشاره أثناء اعتماده في الاجتهاد.

أمّا الواقعية في الثقافة الوضعية فهي واقعية تقوم على نزعات مختلفة ومتضاربة، وقد

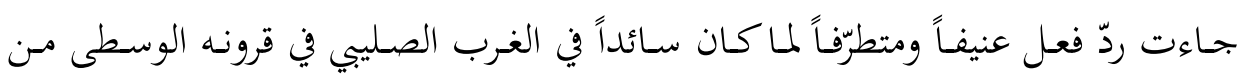

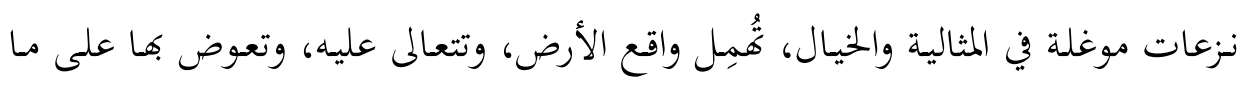
كـان يصـيبها مـن الإحبـاط والفشـل، ويلحقهـا مـن الحرمـان المـادي والأدبي في بيئـات تحكمها وتُوجِهها مذاهب وفلسفات أقل ما يقال عنها إنّا لا تلائمم فطرة الإنسان. إذّا واقعية تلغي الغيب من حياة الإنسان واهتماماته. وإن تساهلت معه فإِّها تَعُدُّه أمراً ذاتياً معيباً، أقرب مـا يكون إلى مرض النفس. وهي تفرض على هذا الإنسـان الارتباط

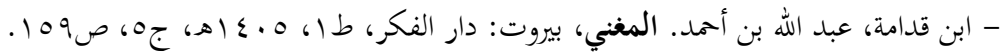

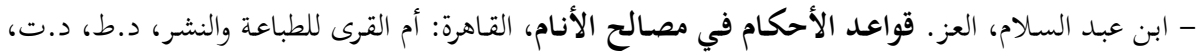

$$
\begin{aligned}
& \text { جr، صדr ا. }
\end{aligned}
$$

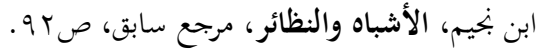

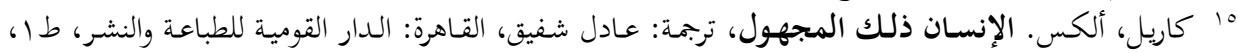


بالواقع المعيش، والانككباب عليه لفهمه وتستحيره في تحقيق المزيد من الرفاه المادي الذي

هو الغاية القصوى للحياة عنده. 17

\section{ثانياً: العرف في الدراسات الاجتماعية والقانونية}

تحـوي الدراسـات الاجتماعيـة العديـد مـن المصطلحات التي يلامس معناهـا العـرف

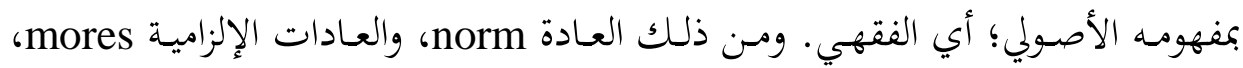

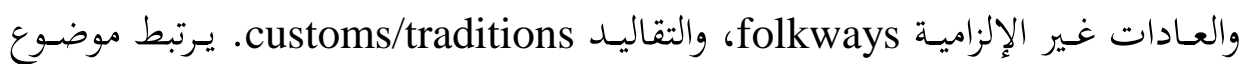
العرف أيضاً بالثقافة culture ضمن مفهومها العام؛ إذ يُعَدّ العرف مظهراً للثقافة المحلية

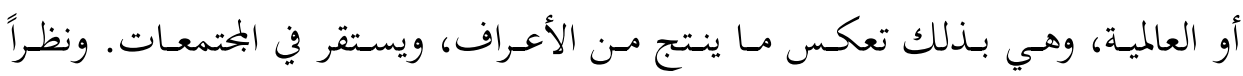
للتلازم والتأثير بينهما؛ فقد أصبح المفهومان مرتبطين متداخلين في المعنى والثبوت.

وقد اختص علم الاجتماع بالنظر إلى العادات والتقاليد التي ينشئها المجتمع ويرسخها

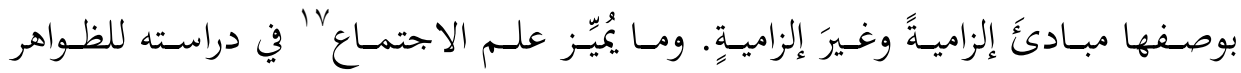

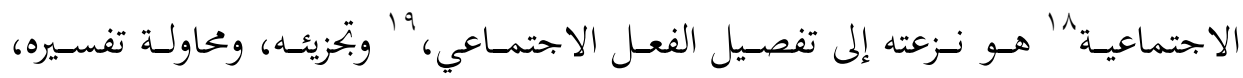

17 برغوث، الطيّب. الواقعية الإسلامية في خط الفعالية الحضسارية، دمشق: مركز الراية للتنمية الفكرية، طا،

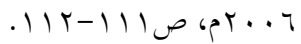

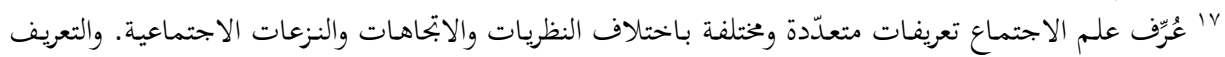

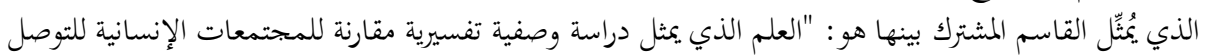

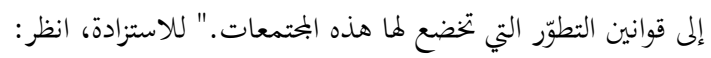

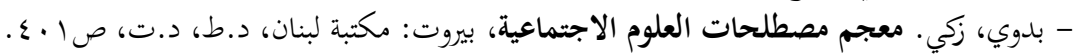

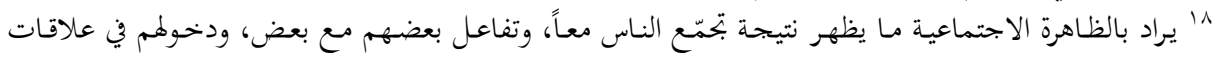

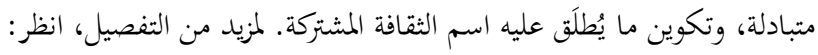

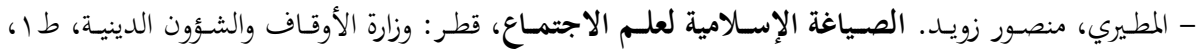
rا

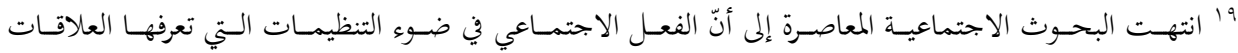

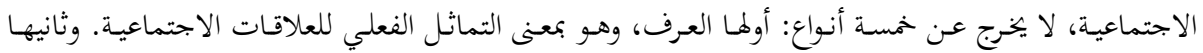

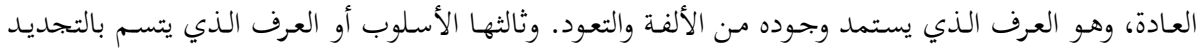

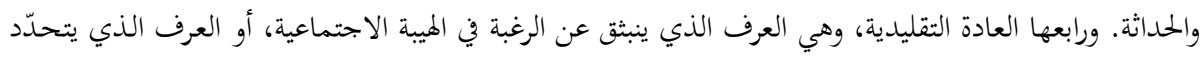

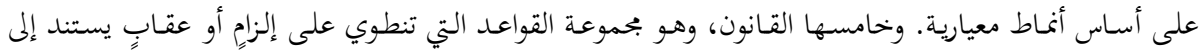

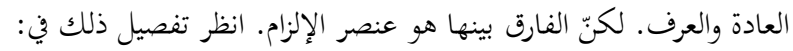




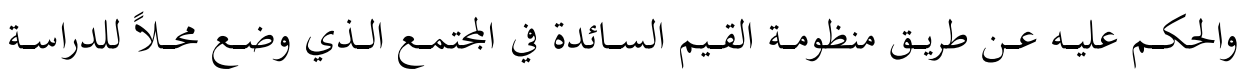

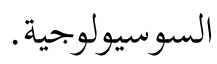

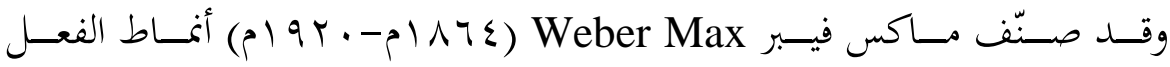

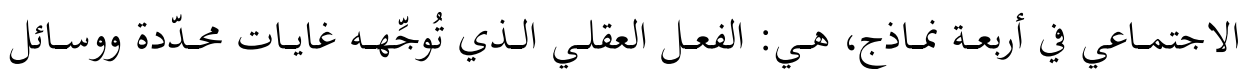

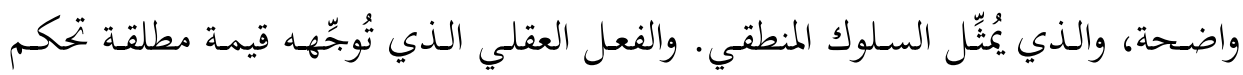

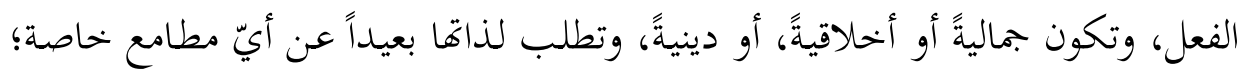

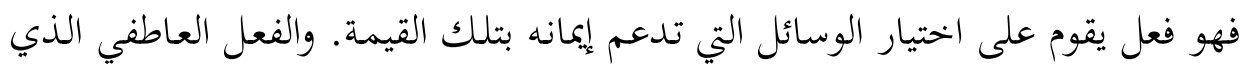

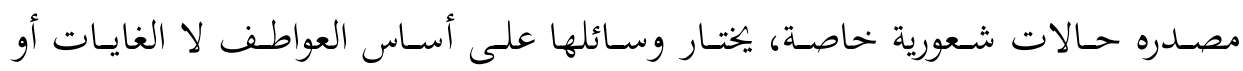

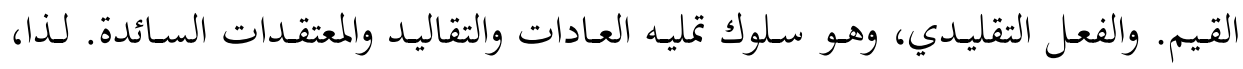

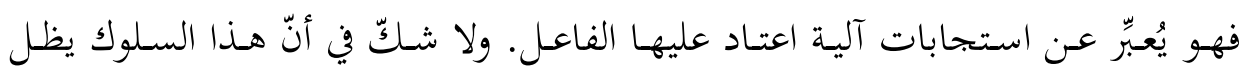

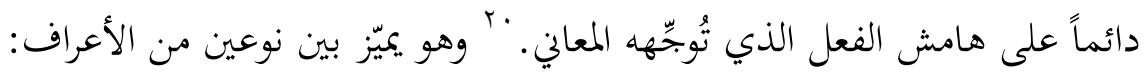

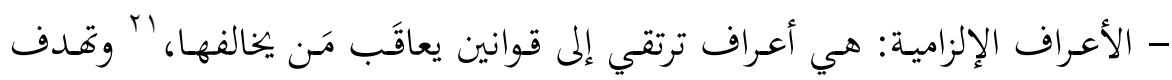
إلى تقويم السلوك العام، وصولاً إلى تحقيق التنمية الاجتماعية.

- الأعراف غير الإلزامية: هي أعراف اتفق الناس على حجيتها وجدواها في تنمية

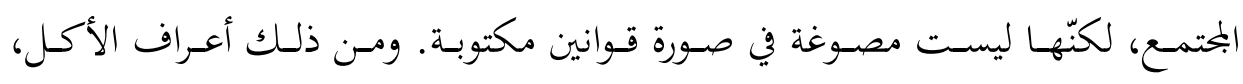

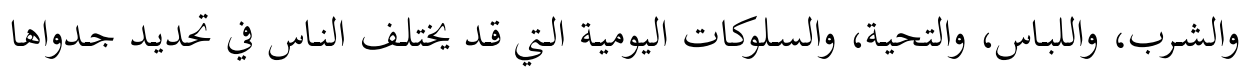
العام.

ومن خصائص الأعراف في المنظور الاجتماعي إمكانية التحايل عليها وانتهاكها من

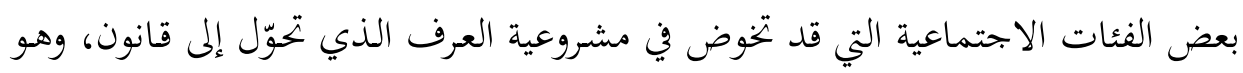

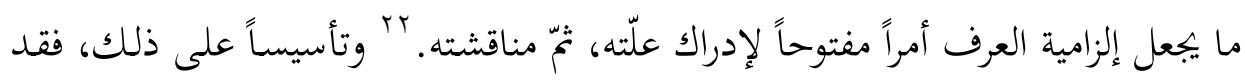

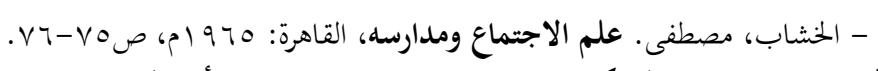

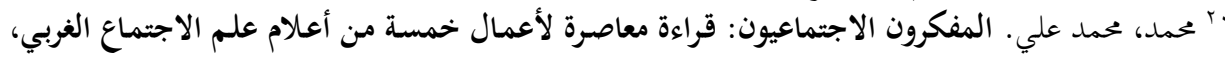

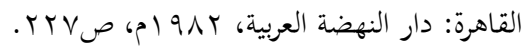

${ }^{21}$ Richard T. Schaefer. Sociology, New York: Mc Graw. Hill Book Company, 1989, p.72.

${ }^{22}$ Ibid, p.73. 


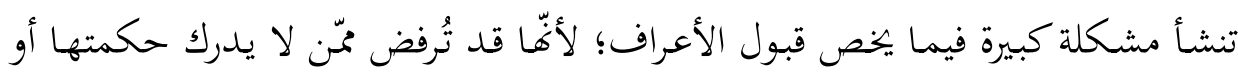

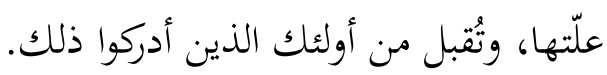

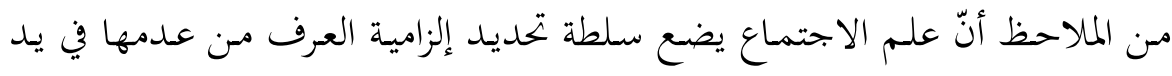

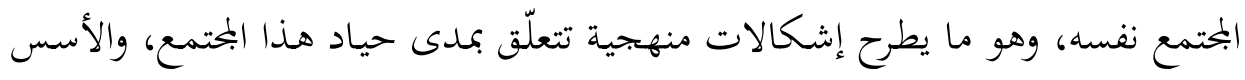

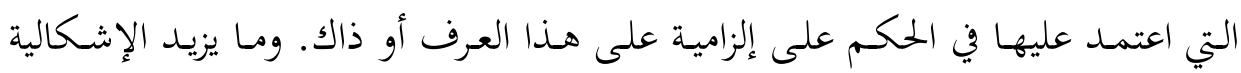

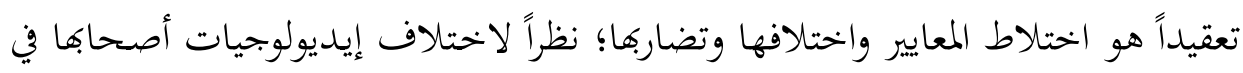

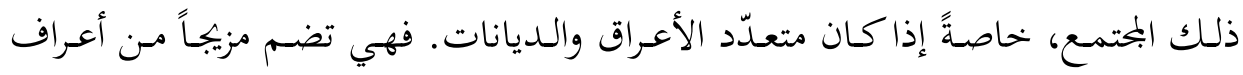

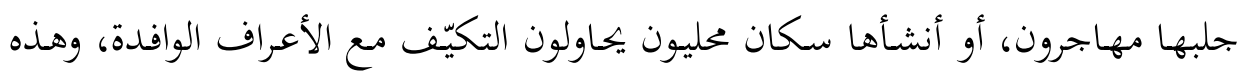

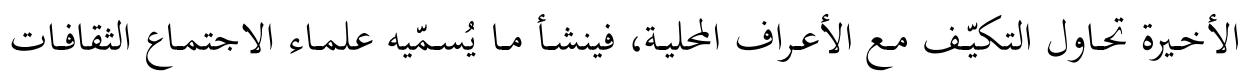

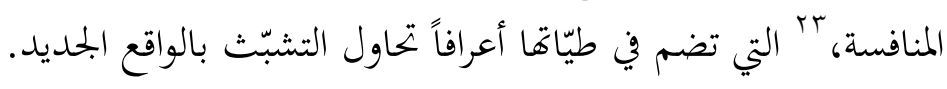

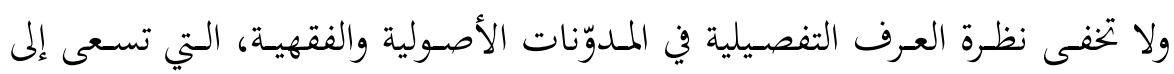

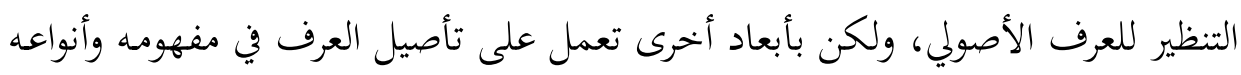

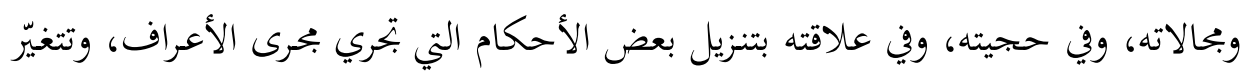

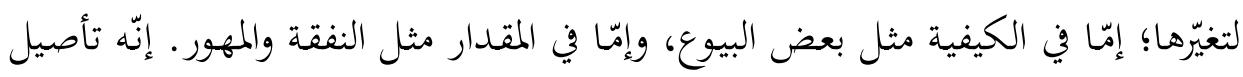

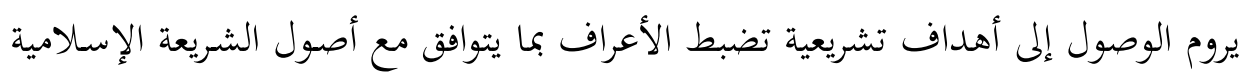

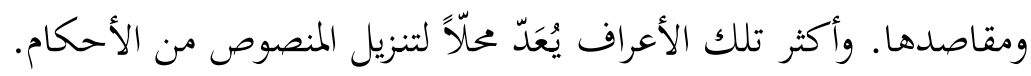
أمّا الأعراف المستجدة فلها تأثير في مصالح الناس العامة، ولا سيّما ضبط حقوقهم

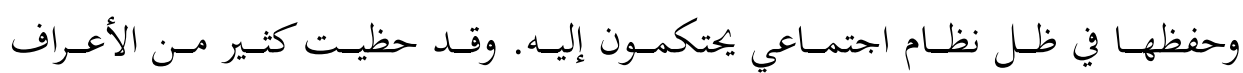

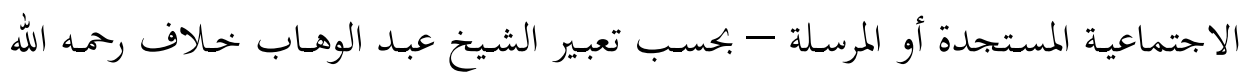

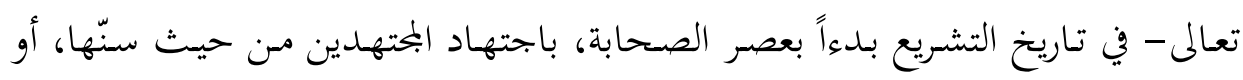

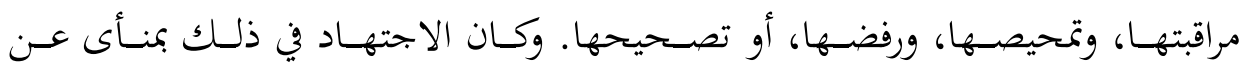

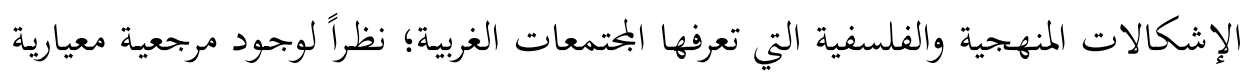

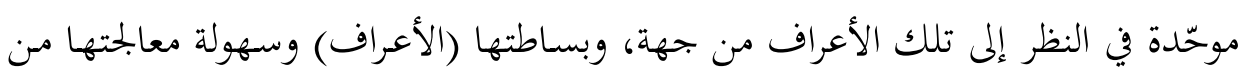

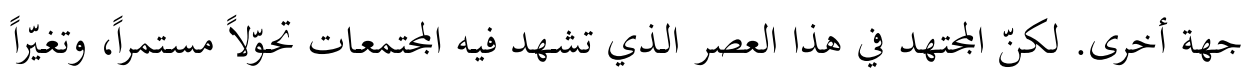

${ }^{23}$ Ibid, pp.78-79. 
لافتاً للانتباه، خاصةً في ظل التقارب العالمي الذي فرضته العولمة بكل أبعادها الاقتصادية

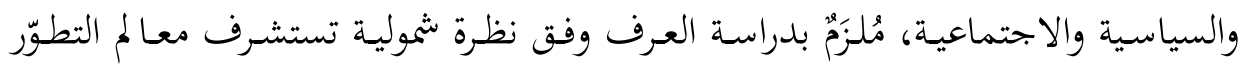

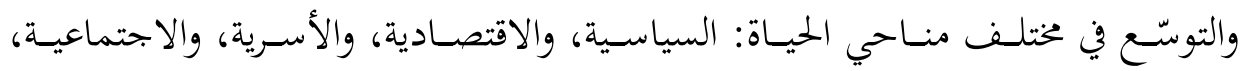

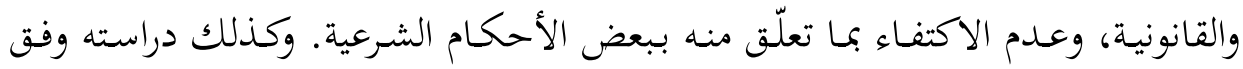

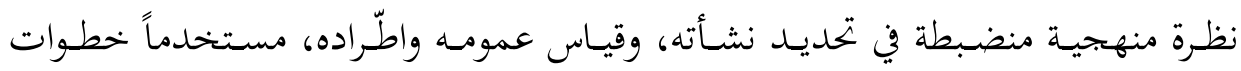

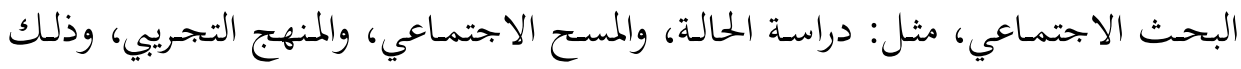

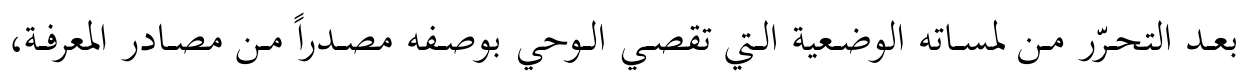

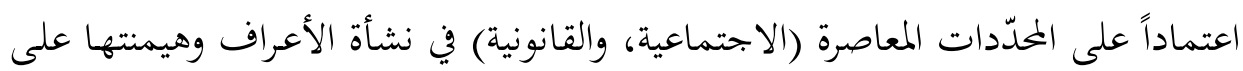

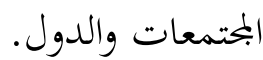

وفيما يخص القـانون الوضعي، فإنّ العرف في اصطلاح رجال القانون الخناص، هو

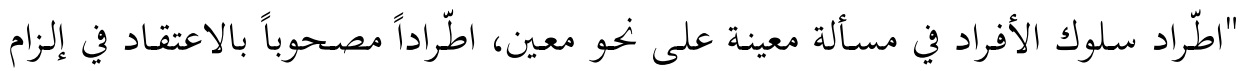

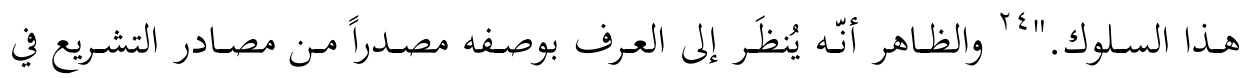
القانون الوضعي، بالرغم من وجود بعض الاختلافات في ترتيبه بحسب القوانين والدساتير

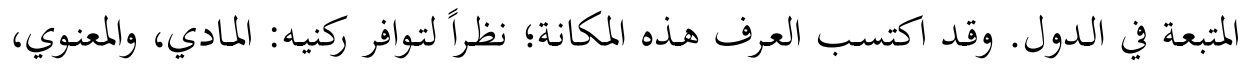
شأنه في ذلك شأن العرف الأصولي.

يستمد العرف القانوين صدقه وحجيته من اطراده وعمومه بين الناس، بكيث يصبح

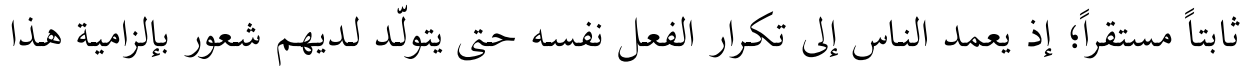

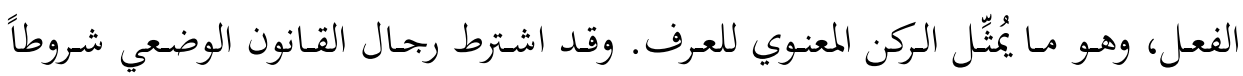

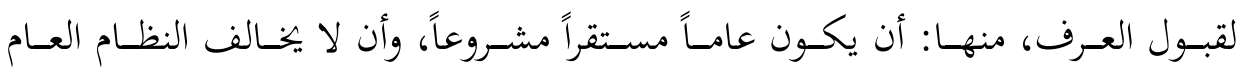
والآداب.

وعلى العموم، فإنّ الإشكالات التي طرحناها بخصوص العرف الأصولي موجودة في

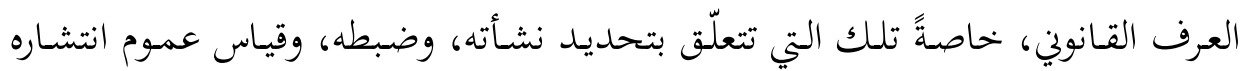

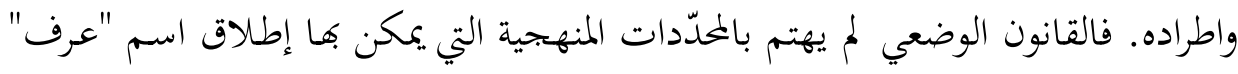




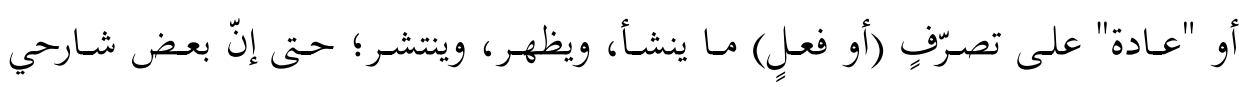

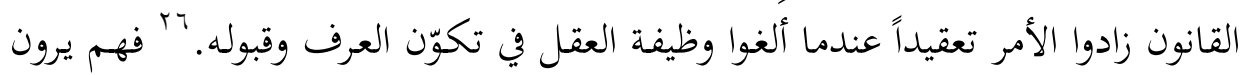

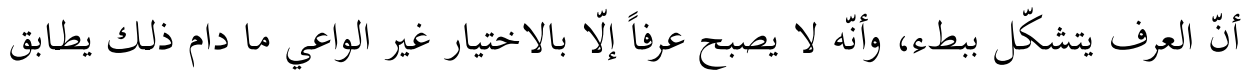

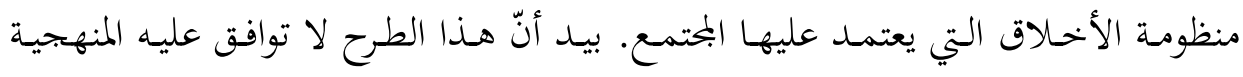

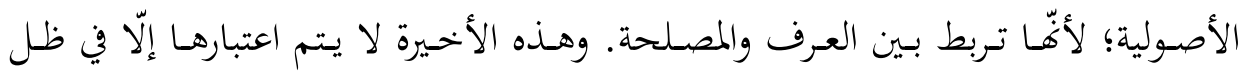

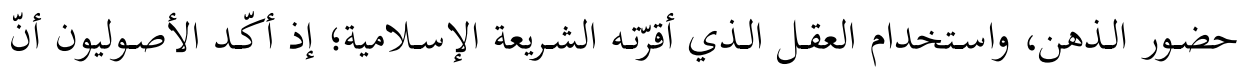

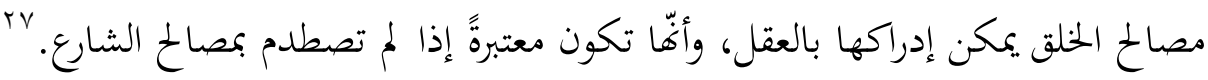

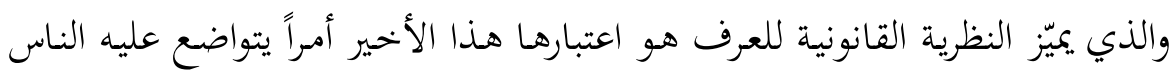

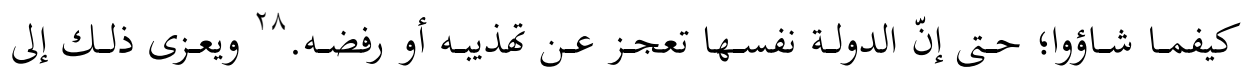

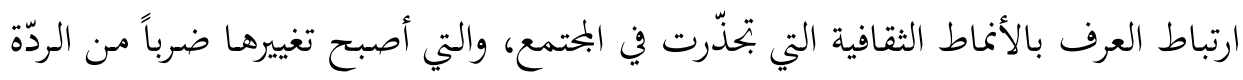

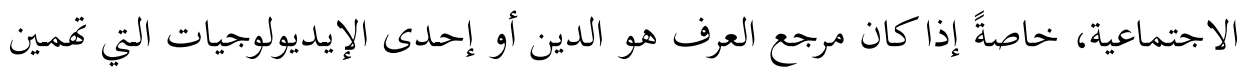

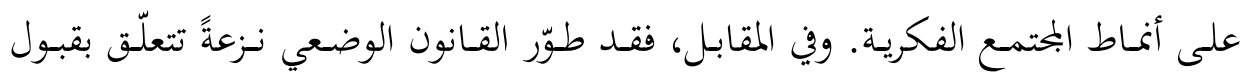

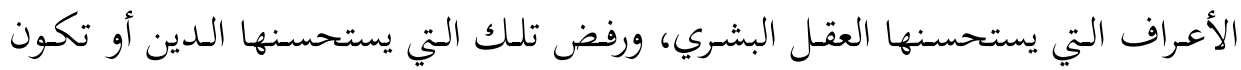

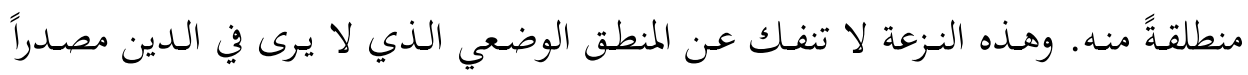

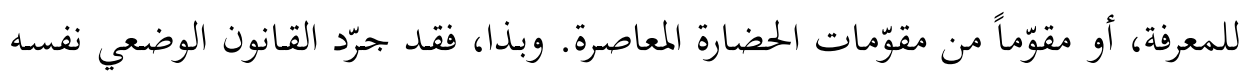

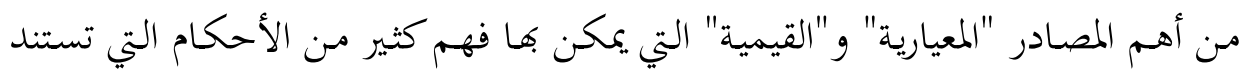

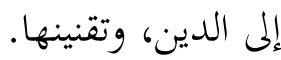

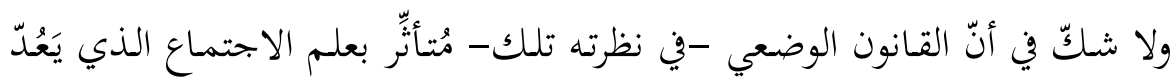

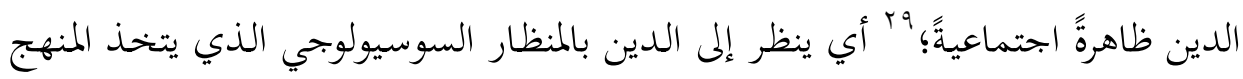

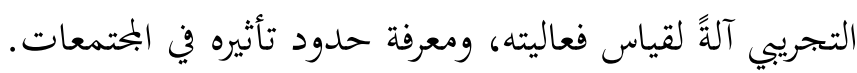

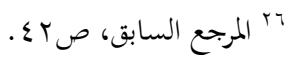

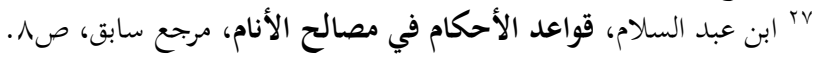

${ }^{28}$ See Eric A. Posner. Law and Social Norms, Harvard: Harvard University Press, 2000, p.8.

${ }^{29}$ Kammeyer Pitzer. Sociology: Experiencing Changing Societies, $7^{\text {th }}$ ed. London: Ally and Bawn, 1997, p.536. 
مَّّا تقدّم بند أنّ علم الاجتماع ينظر إلى بعض التشريعات الإسلامية بوصفها مضض

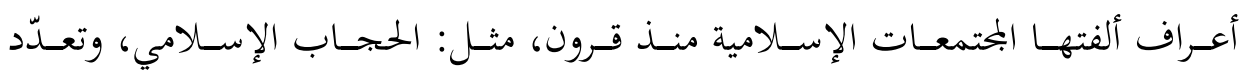

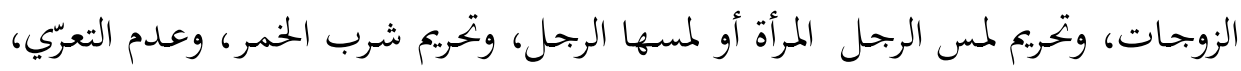

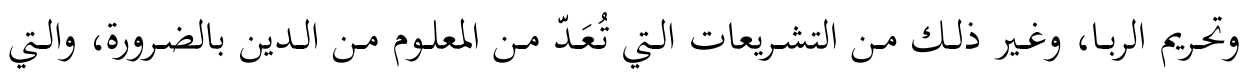

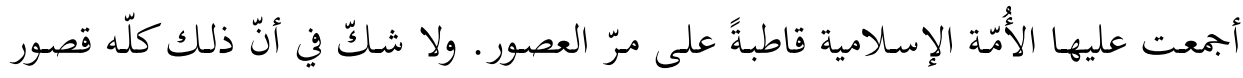
في فهم طبيعة الدين، ودوره "القيمي" و "المعياري" في حياة الأفراد والبحتمعات.

\section{ثالثاً: العرف والتغيّر في ضوء النظريات السوسيولوجية والثقافية المعاصرة}

\section{ا ـ العرف والتغيّر الثقافي:}

يرى العرف الأصولي أنّ الأحكام الشرعية المبنية على الأعراف تتغيّر بتغيّرها، وتثبت

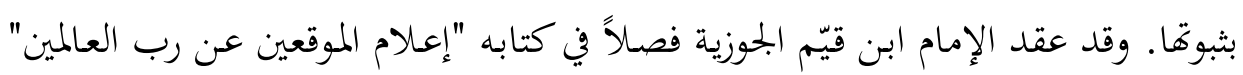

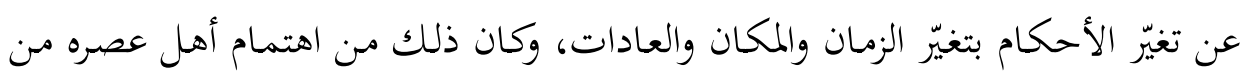

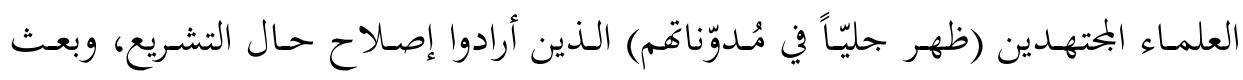
روح الواقعية فيه آنذاك؛ إذ كان عصرهم عصر جمود على المنقولات وتقليد السابقين من إنس المحتهدين، فقرّروا معرفة العرف، وعدِّه شرطاً من شروط تحقّق أهلية الاجتهاد في المحتهد.

يزخـر التشريع الإسـالمي بأحكام "عرفية" عكسـت مرونته وفعاليته -سبق التعرّض لهذا فيما سبق من البحث- لكنّ الأسئلة التي نطرحها في هذا السياق تأخذنا بعيداً عن الإسن

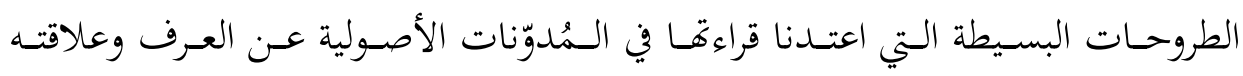
بالتشريع. ومن أهم هذه الأسئلة: ما علاقة العرف بالثقافة؟ كيف يمكن نشوء العرف في

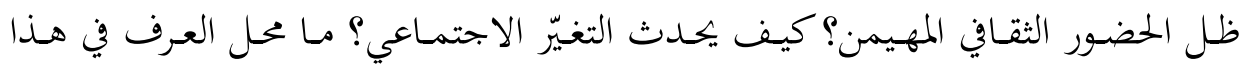

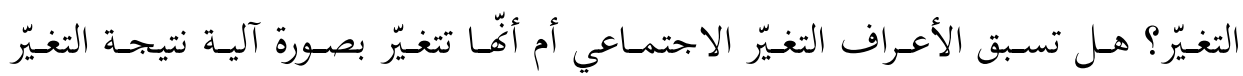
الاجتماعي والثقافي؟ وإذا كان الأمر يقتضي هذا التأصيل العلمي، فهل يُفترض في الفي الفقيه أو الأصولي المعاصر أن يدرك العرف بأبعاده الاجتماعية والثقافية، بحيث يزاوج بين الفقهـ

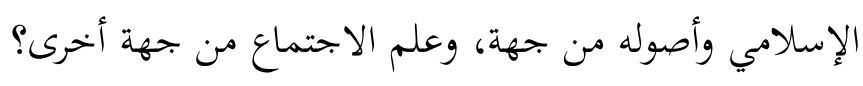




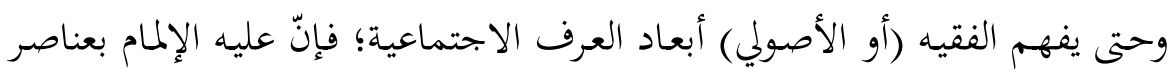

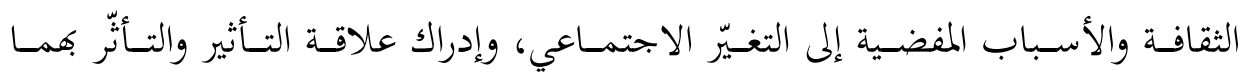

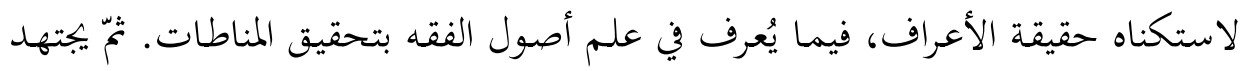

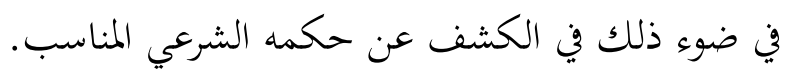

يتصل العرف مباشرةً بالثقافة التي ينشأ فيها؛ فهو مكوّن رئيس من مكوّناتها، وهو

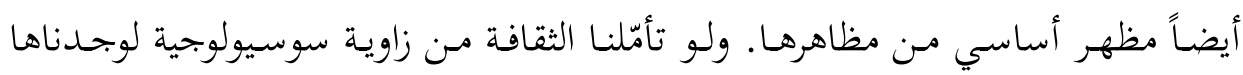

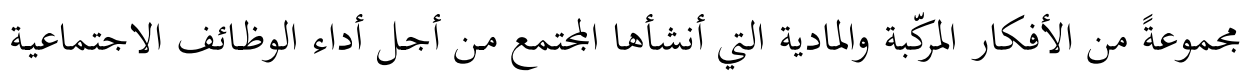

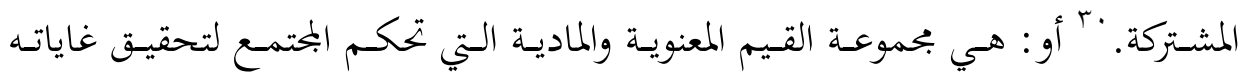

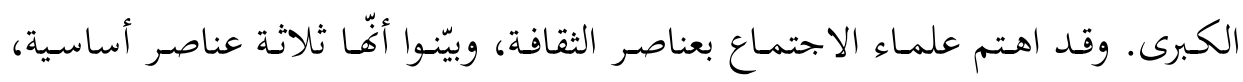

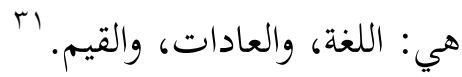
تمثّل العادات أو الأعراف الركيزة الأساسية لثقافة أيّ بحتمع؛ ذلك أنّ المجتمع يلفظ

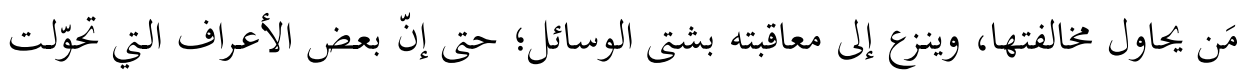

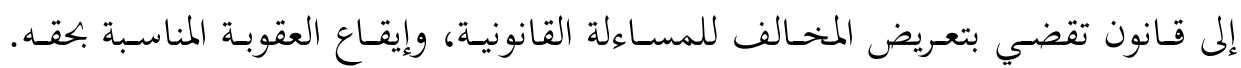

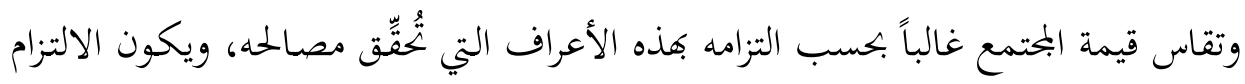

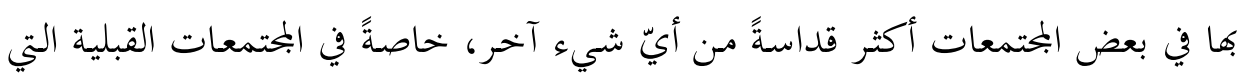

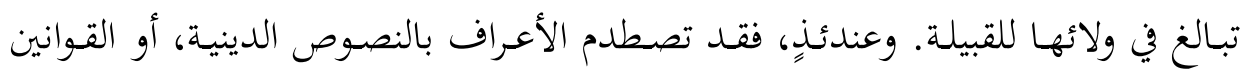

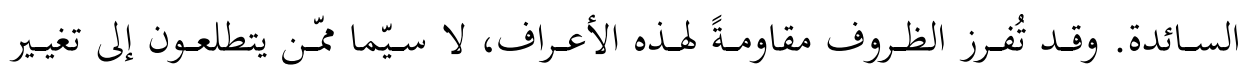
الأوضاع القائمة والعادات القديمة، أو تمّن أوجدوا ثقافات لقدات مناوئة أو فرعية.

\section{r r. العــرف والتغيّـر الثقـافي فـي ضـوء النظريـات السوسـيولوجية والثقافيـة \\ المعاصرة:}

تفـترض هـذه الدراسة أنّ العرف يتغيّر بـالتغيّر الثقافي الذي يشهـده المحتمع. وهـذا

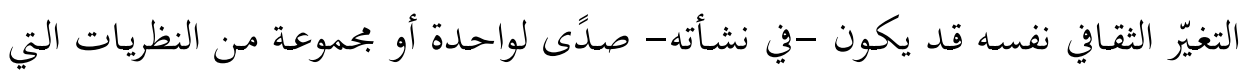

${ }^{30}$ Kammeyer. Sociology, p.55.

${ }^{31}$ Richard. Sociology, pp.73-82. 
طرحها علماء الاجتماع من أجل تحليل التغيّر الثقافي في المجتمع. وتقتضي طبيعة الدراسة

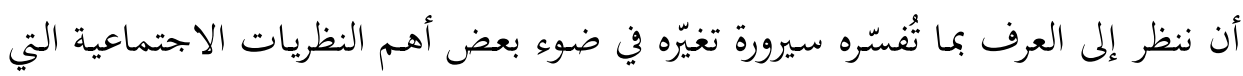

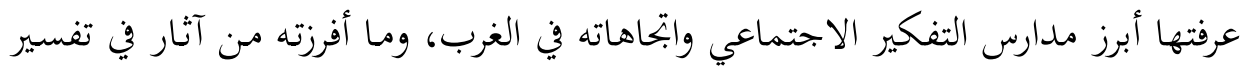

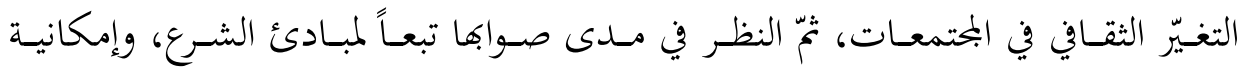
تكاملها مع النظرية الأصولية في تفسير العرف وما يعتريه من تغيّر وتطوّر.

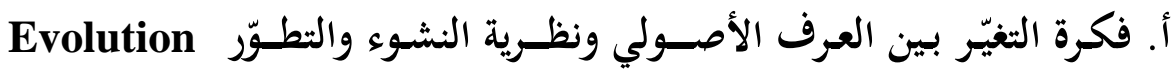

\section{:Theory}

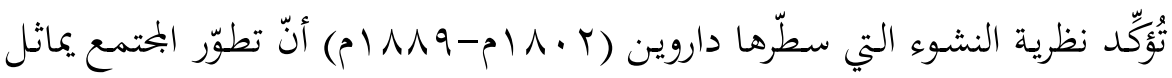

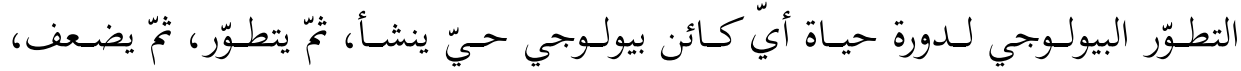

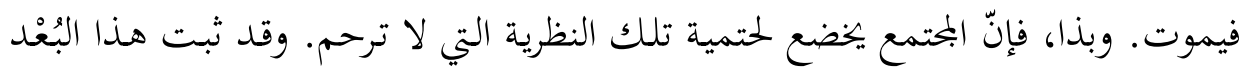

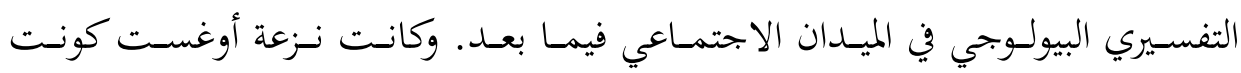

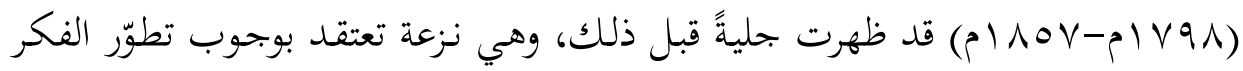

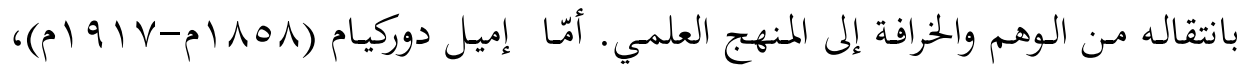

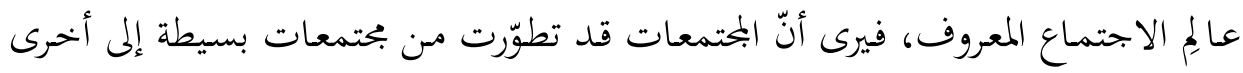

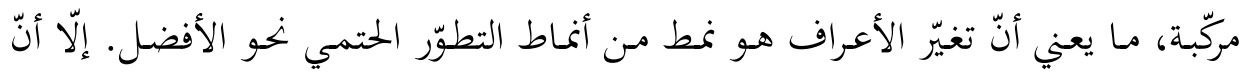

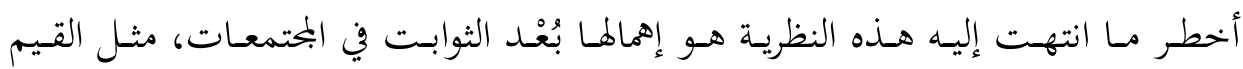

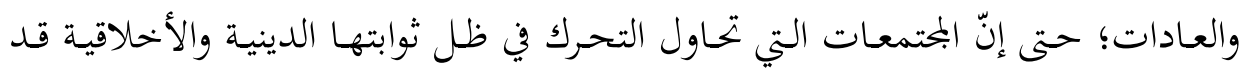

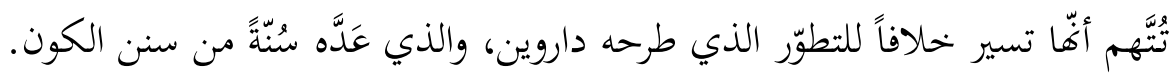
لا شكّ في أنّ فكرة التغيّر والتطوّر موجودة في التشريع الإسلامي - كما سبق بيانه

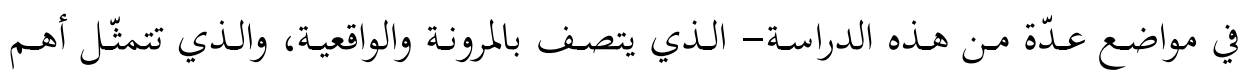

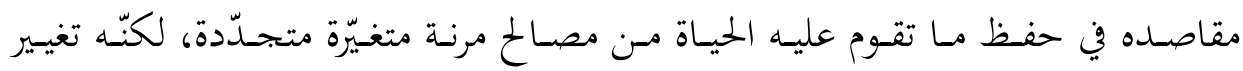

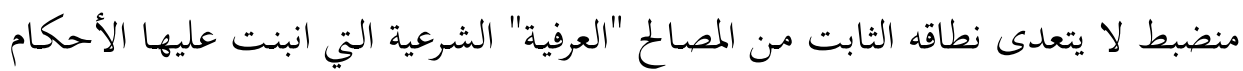

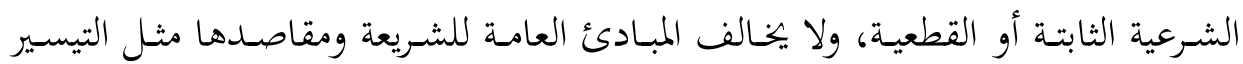
والعدل. فهذه الضوابط بحتمعةً هي ما اشترطه الأصوليون في العرف لإقراره والعمل به. 


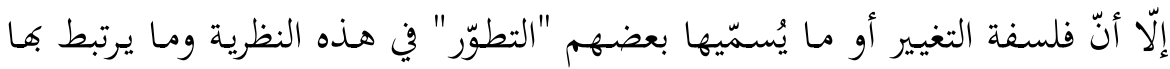

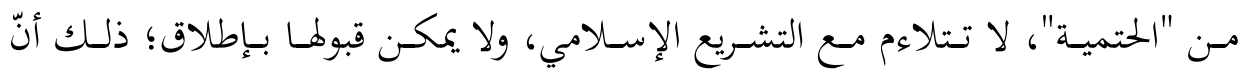

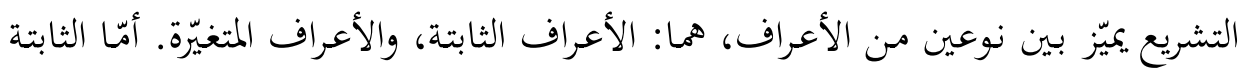

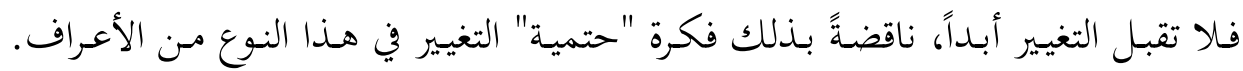

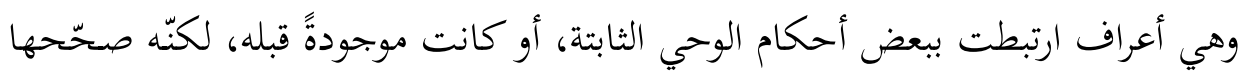

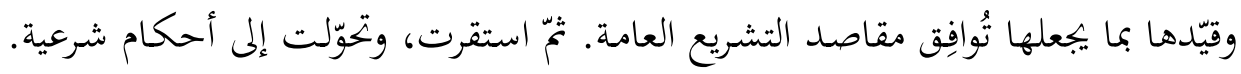

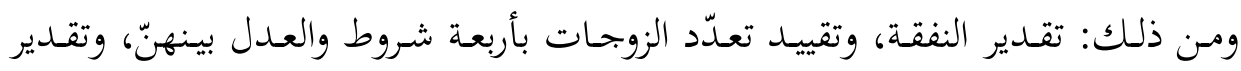

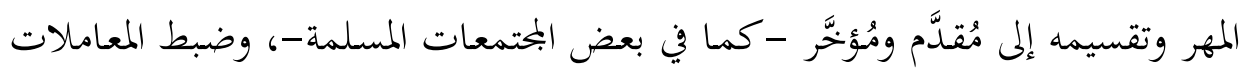

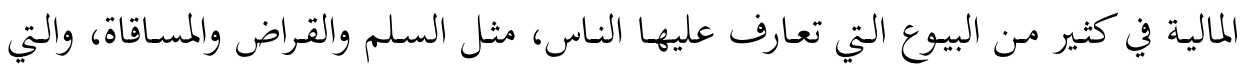

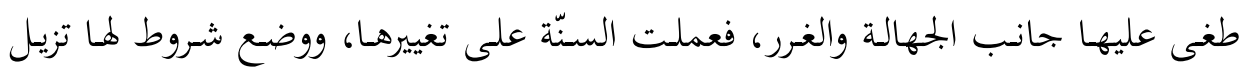

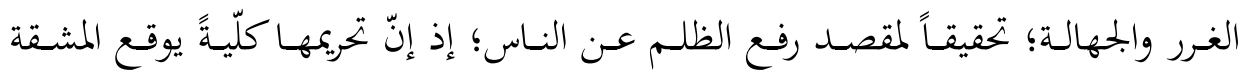

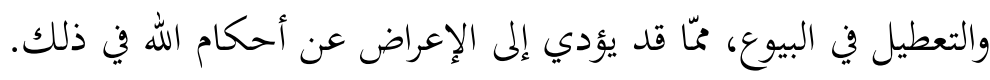

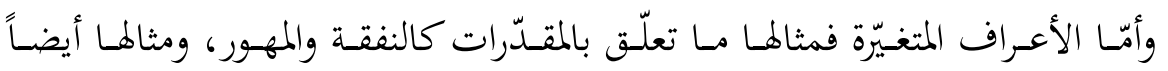

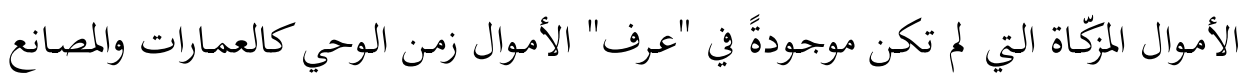

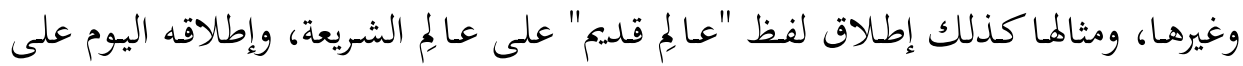

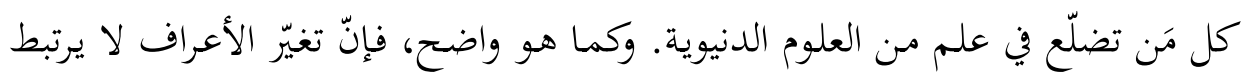

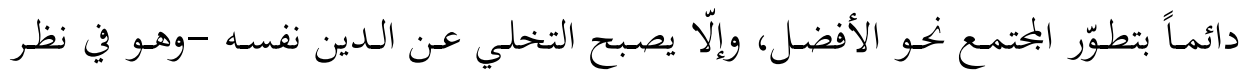

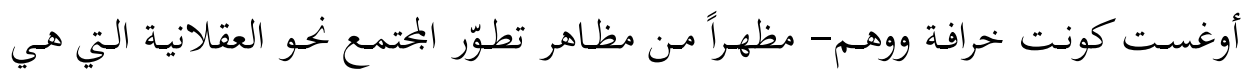
أفضل من الخرافة التي تنشرها المعتقدات الدينية في نظر هذه الفئة من من الفيلاسفة.

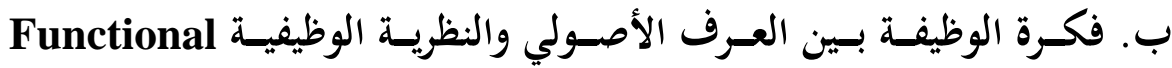

\section{:Theory}

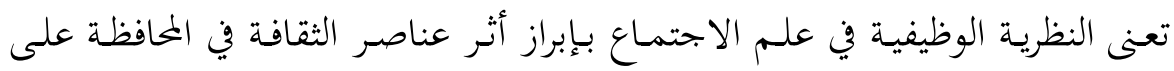

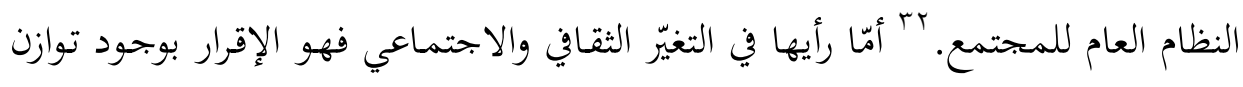

${ }^{32}$ Kammeyer Pitzer. Sociology: Experiencing Changing Societies, p.617. 
اجتمـاعي في المجتمع على الدوام بصرف النظر عن طبيعـة التغيّرات وتقلّبّ الأحسوال.

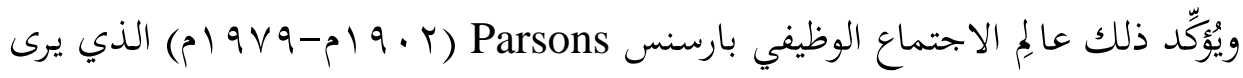

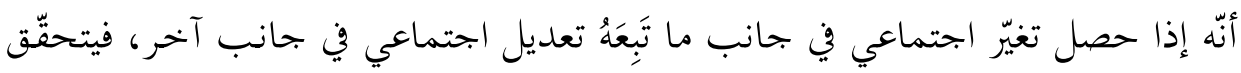

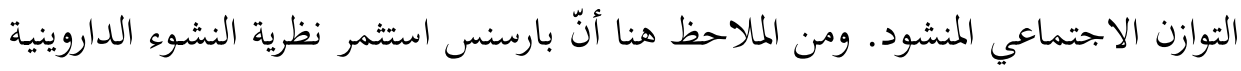

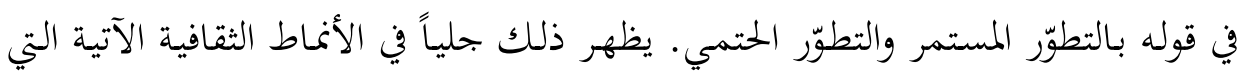
أكّد بارسنس أثّا آيلة إلى التغيّر لا محالة:

ا ـ النمط الاختلافي نتيجة التحول والتغيّر كمظاهر للتطور : وفيه يتحوّل المجتمع من

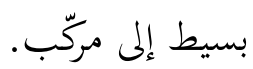

r. النمط التحديثي: وفيه تصبح المؤسسات الاجتماعية أكثرَ تخصّصاً. r. النمط الاستيعابي: وفيهـ تُستوعَب الشرائح الاجتماعية المهملة في المؤسسـات الاجتماعية التي دأبت غالباً على إقصاء هذه الشرائح. ع. ـ نمط القيم الجحديدة المستحدثة: وفيه يقوم البحتمع باعتماد بحموعة من القيم التي

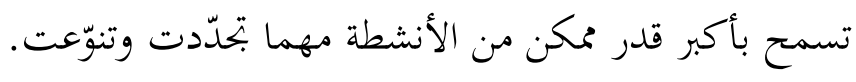

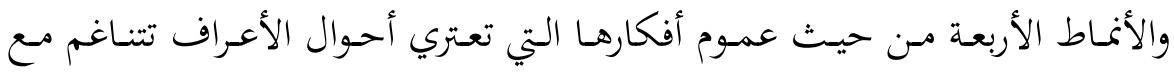

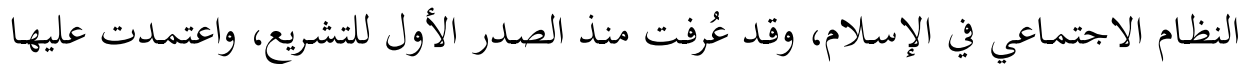

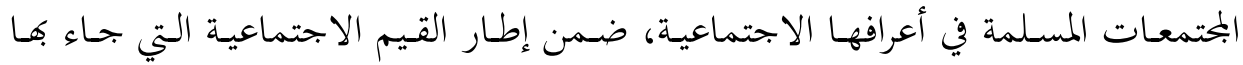

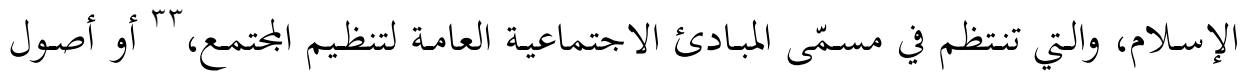

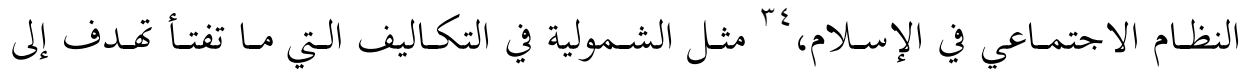

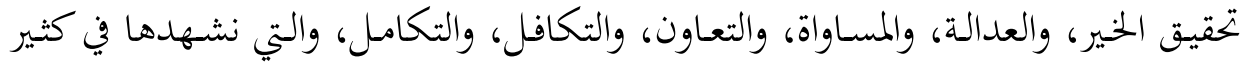

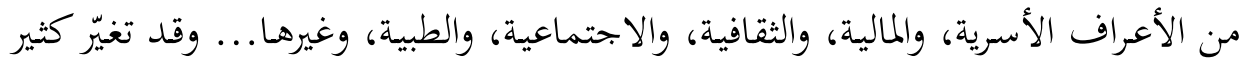

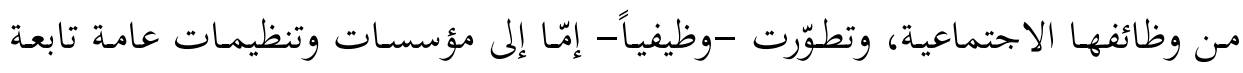

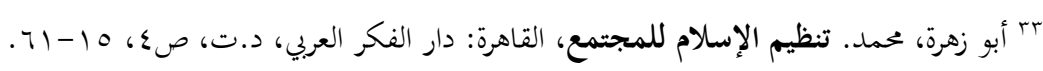

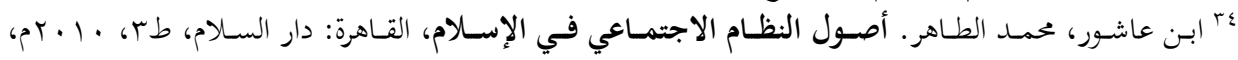




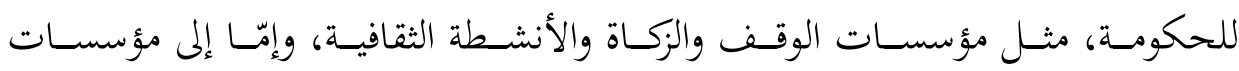

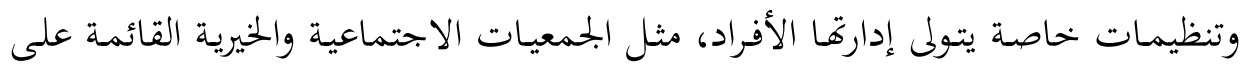

$$
\text { مبادئ الشريعة "الاجتماعية". }
$$

والأعراف على اختلافها تسير في أداء وظائفها مـن حال البساطة إلى أحوال أكثر

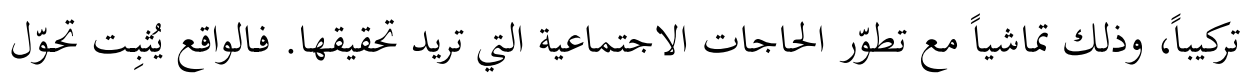

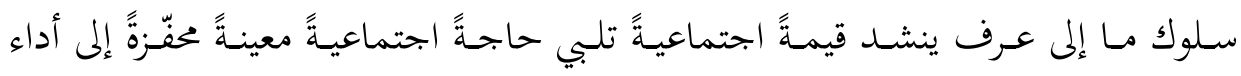

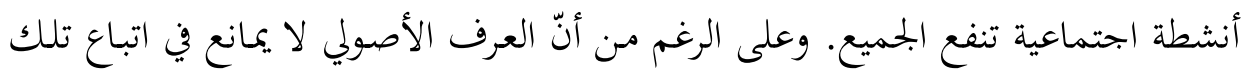

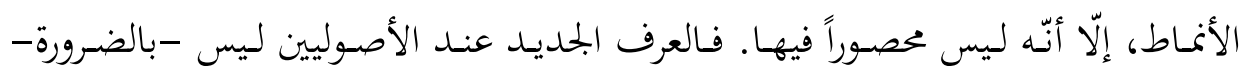

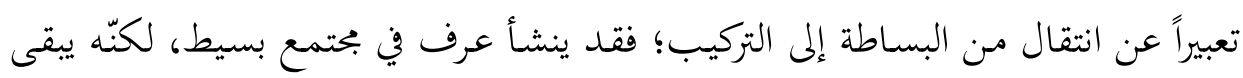

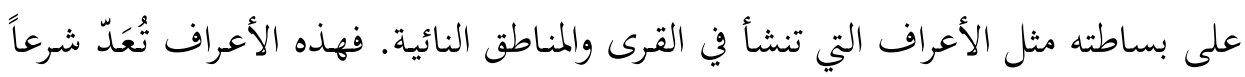

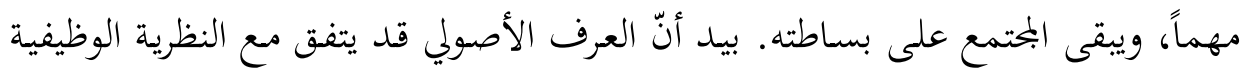

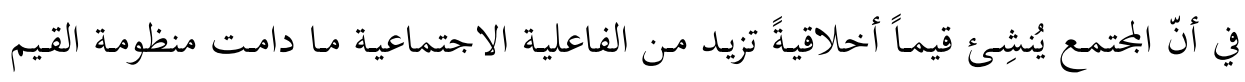

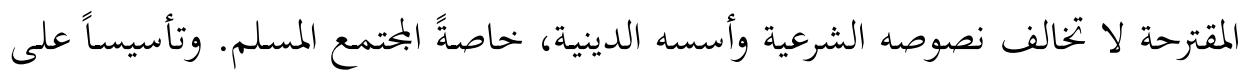

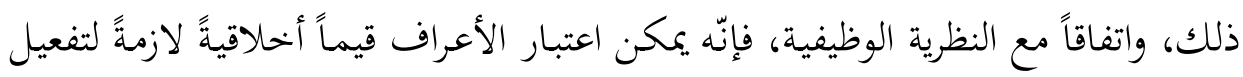
حركة المجتمع وتطوير أدائه.

\section{ت. فكرة النزاع بين العرف ونظرية النزاع Conflict Theory:}

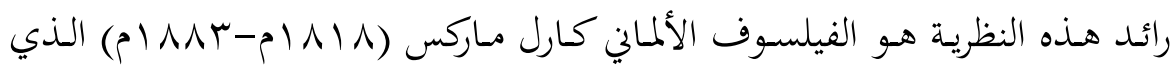

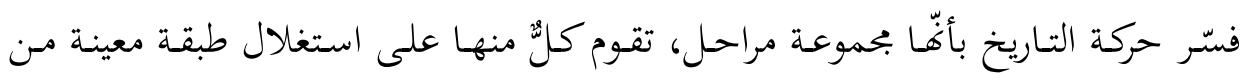

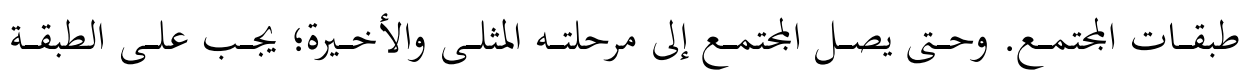

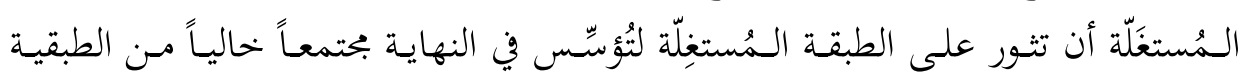

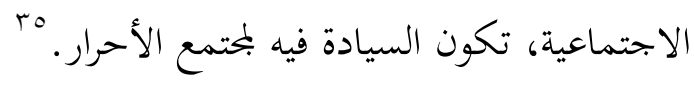

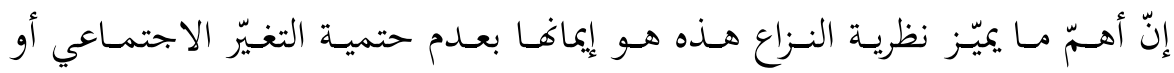

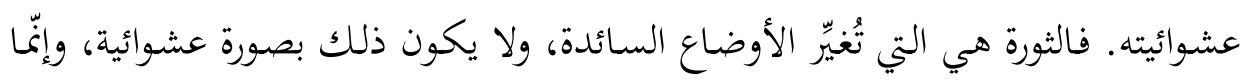

${ }^{35}$ Kammeyer Pitzer. Sociology: Experiencing Changing Societies, p.618. 
بقدر كبير من التخطيط والمنطق. وهذا ينسحب أيضاً على تغيير الأعراف السائدة؛ إذ يمكن للثورة القضاء عليها من أجل استبدال أعراف أكثر فاعليةً بها.

ولو أردنا أن نقارن هذه النظرية بنظرية العرف الأصولية لوجدنا أنّ العرف الأصولي

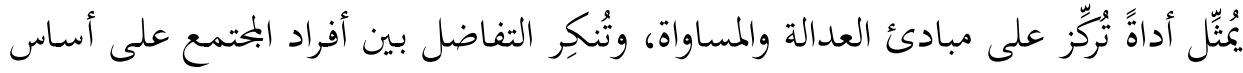

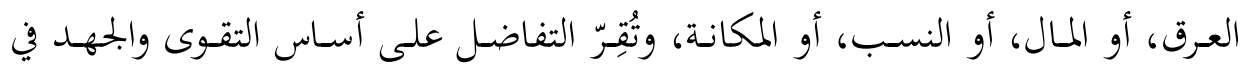

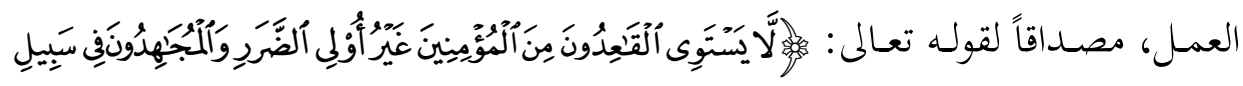

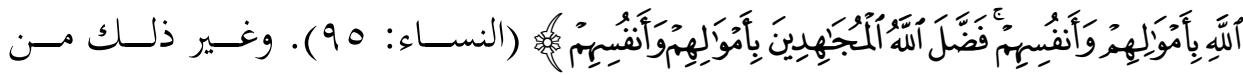
النصوص الشرعية الدالة على المعنى نفسه؛ تحقيقاً للعدل، وتمييزاً لطبقات المحتمع بعضهاء

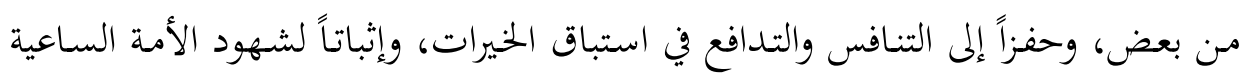

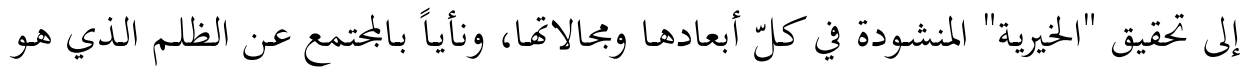

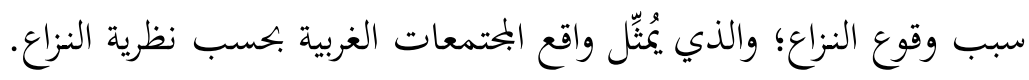
يمكن الاسـفادة مـن هـذه النظريـة في بعض المنـاحي الشـكلية مـن دون المضـمون.

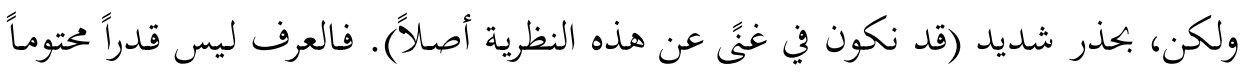

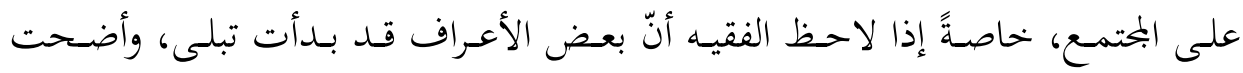

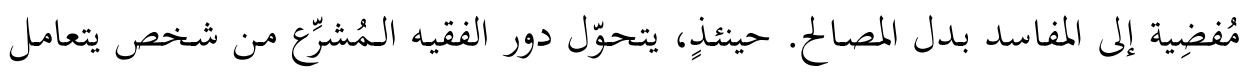

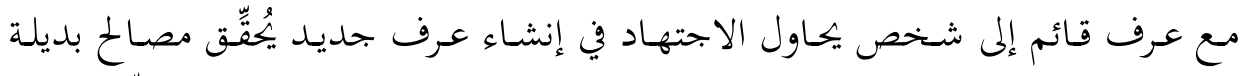

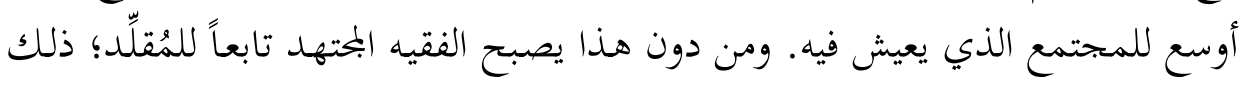

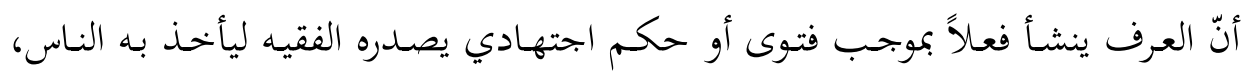

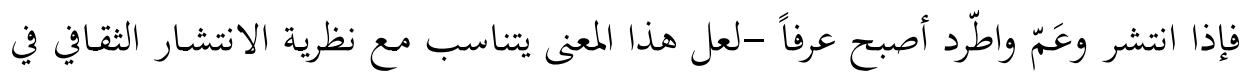

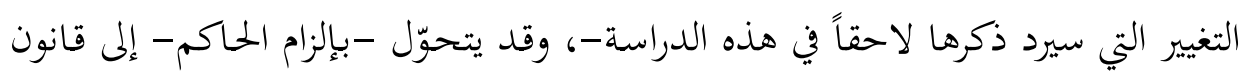

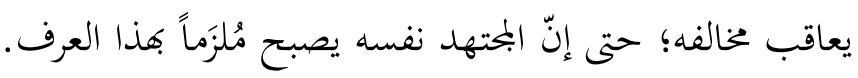

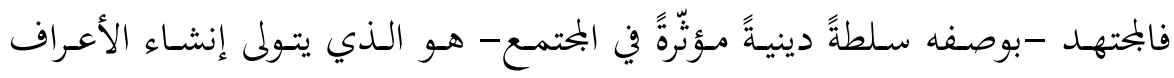

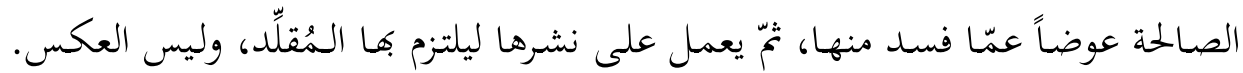

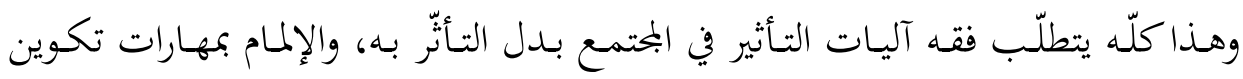
الرأي العـام في قضية مـن القضـايا، وهـو أمـر تختص بـه الدوائر الإعلاميـة التي تستخدم 
أحسث النظريـات في هـذا المجلال. فـالعرف الأصـولي مـدعوّ بقوة إلى إقرار الأعـراف التي

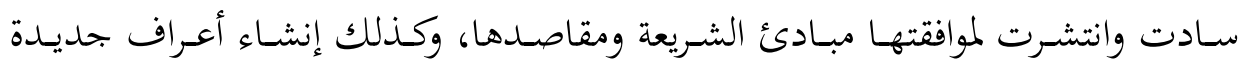
تستلهم قيم الشريعة ومقاصدها، والعمل على بثها في المجتمع لتصبح أعرافاً يسير المجتمع

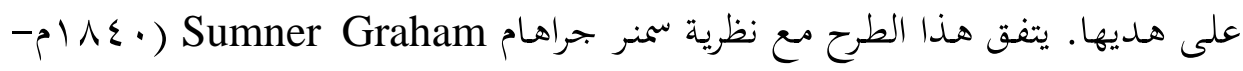

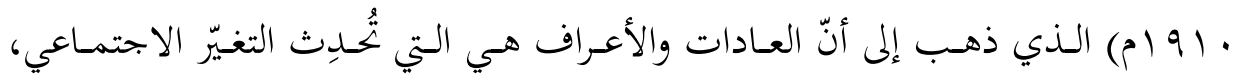

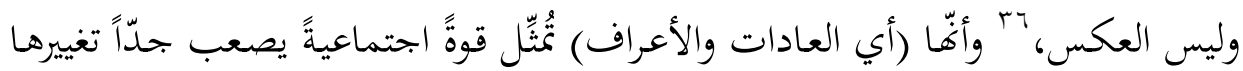
بعد استحكامها.

من جانب آخر، تختلف نظرية العرف الأصولية مع نظرية مور Moore التي تنص

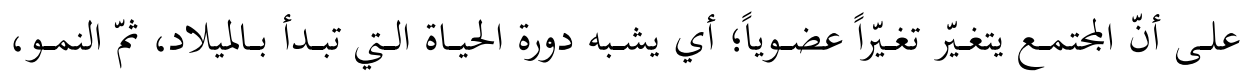

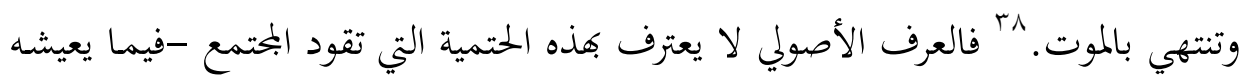

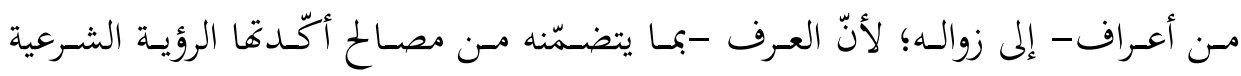

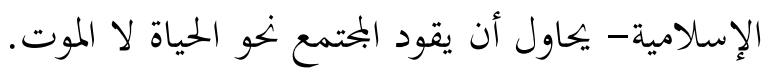

\section{ث. العرف ونظرية الانتشار الثقافي:}

يشير الانتشار إلى تلك العملية التي تتضمّن ذيوع عناصر أو أنساق ثقافية معينة، ينتقل بها اختراع جديد أو نظام جديد من مكانه الأصلي إلى مناطق بحاورة، أو ملاصقة الاصنة أحياناً، حتى تنتشر تدريجياً في العالم كله.

نشأت نظريـة الانتشـار الثقـافي بغرض تفسير التغيّر أو التطوّر في البحتمعـات. وهي

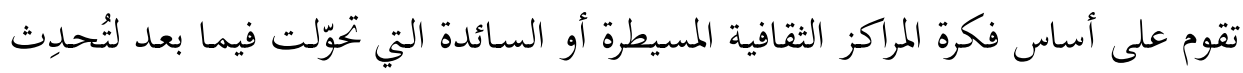

${ }^{36}$ Mohammad Muslehuddin. Sociology in Islam, Lahore: Islamic Publications Limited, 2000, p.43.

${ }^{37}$ Sumner, William Graham, Folkways: A Study of Mores, Manners, Customs and Morals, London: David and Charles Brunel House, 2002, p.3.

${ }^{38}$ Ibid, p.42.

${ }^{39}$ Kroober, A.L ((Diffusion)) in Amitai and Eva Etzioni-Haley (eds), Social change: Sourses, Pa Herus and Consequences, $2^{\text {nd }}$ ed. New work: Basic Books, 1973. pp.140144. 


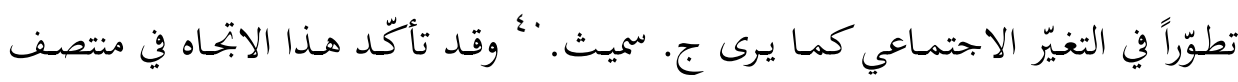

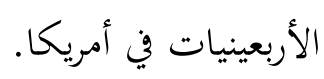

وبحسبـ كروبير، فإنّ "الانتشار ينتج تغيراً للثقافة التي يستقبلها." ا" ومنـه ظهرت

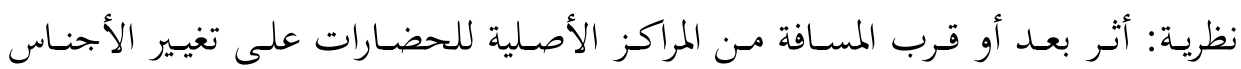

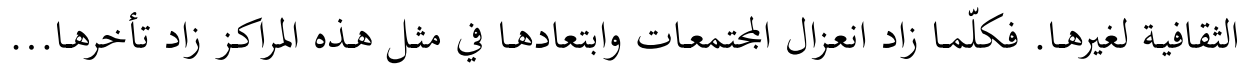

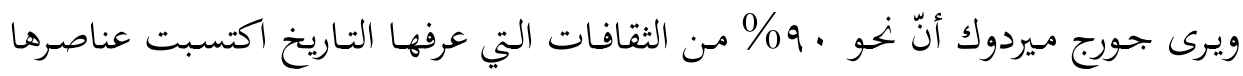

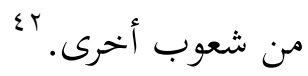

والواضح أنّ فكرة الانتشار في هذه النظرية لا تتعارض مع العرف الأصولي في طريقة

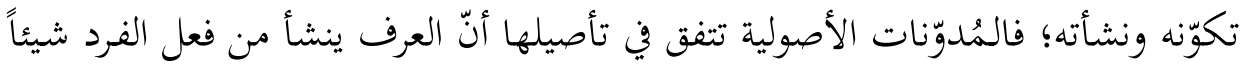

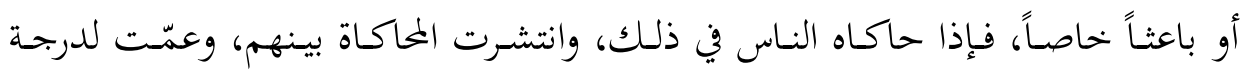
الاطّراد ثبتـت بـذلك عرفاً. وفكرة الانتشـار، بوصفها وسيلةً لما أثرها في تحقيق المصالح

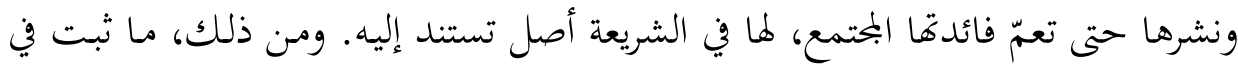

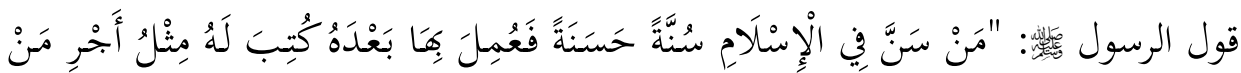

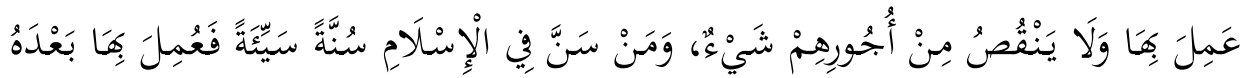

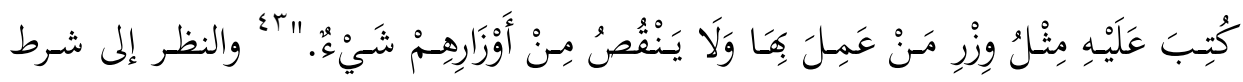
العموم والاطرّاد في ثبوت الأعراف يقوم أساساً على عملية انتشار الفعل في المحتمع. وبنحد

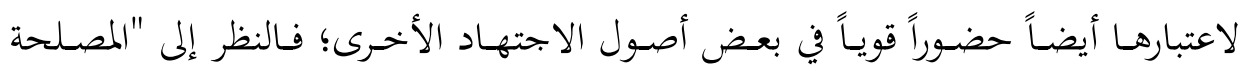

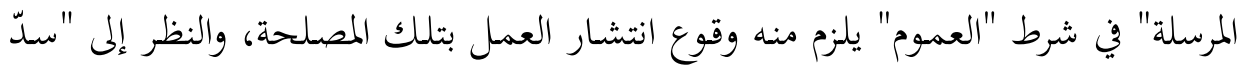

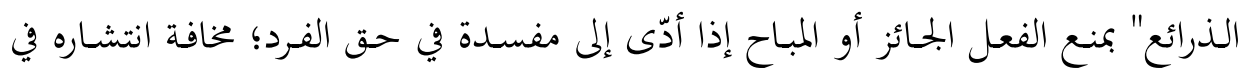

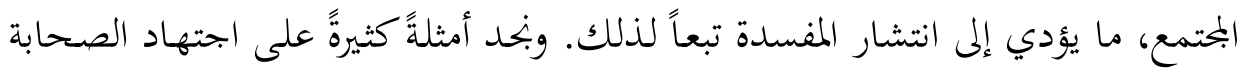

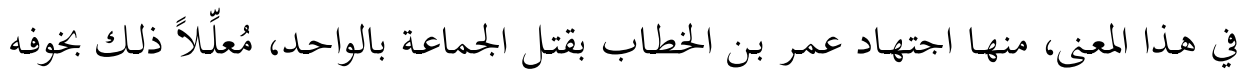
${ }^{40}$ Ibid, p.143.

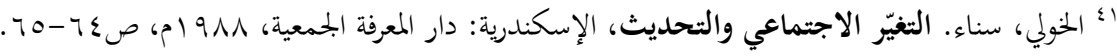

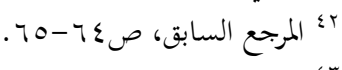

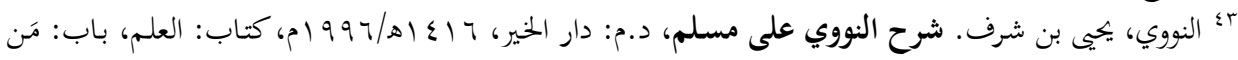




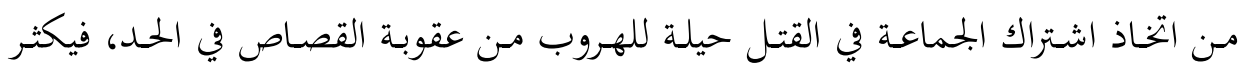

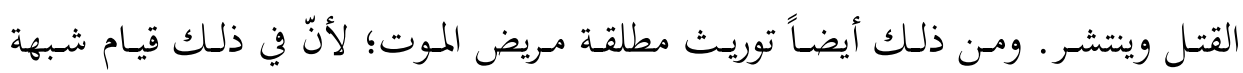

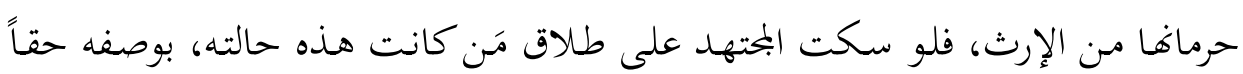

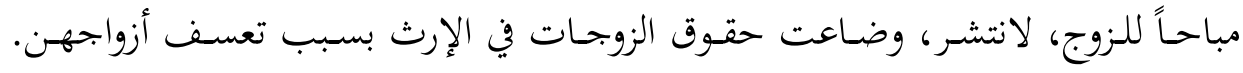

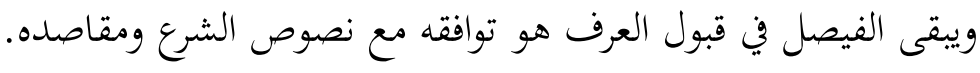

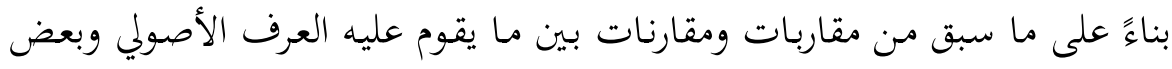

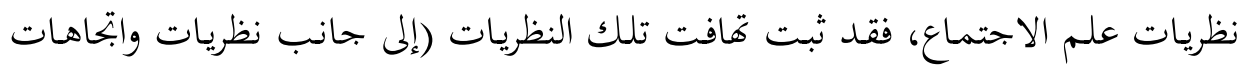

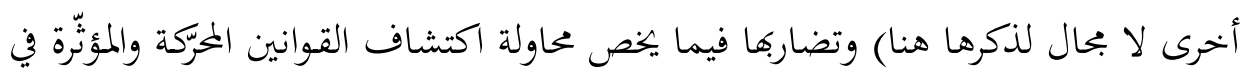

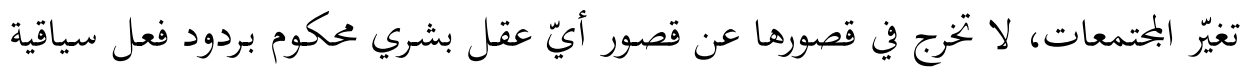

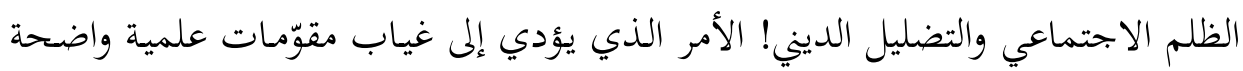

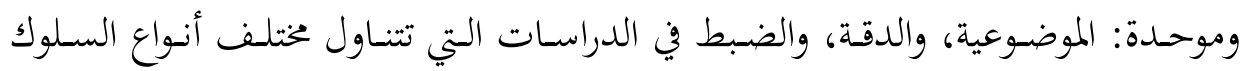

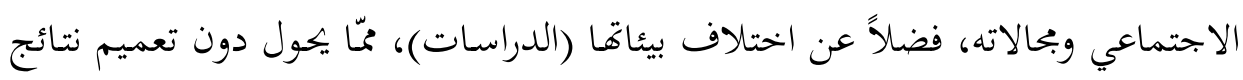

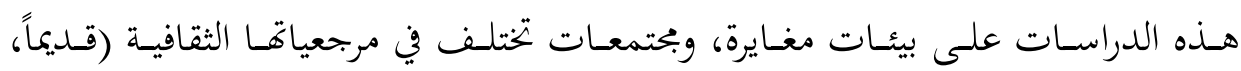
وحديثاً)، ولا يستفاد من تلك الفلسفات أو النزعات الفردية المتنافرة. لكـنّ ذلك لا يمنـع البحـث عـن كيفيـة الاستفادة مـن الأدوات المنهجيـة القياسية

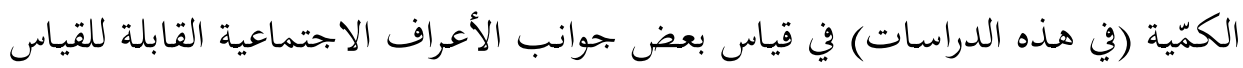
وضبطها؛ إذ لا يمكن إنكار سبق الدراسات الاجتماعية الغربية المعاصرة في هذا المحال.

\section{رابعاً: العُرف وأدوات القياس الاجتماعي}

نأياً عن الاتحاهات والفلسفات التي تعرّرت لتفسير التغيّر الاجتماعي وتطوّره في

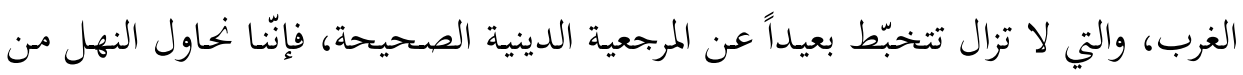

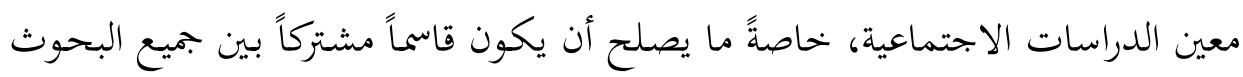

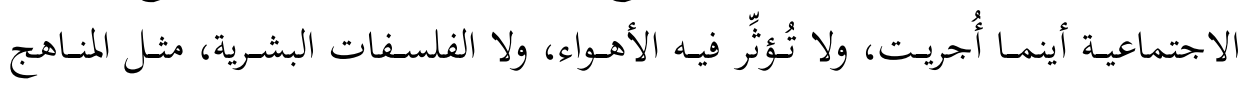

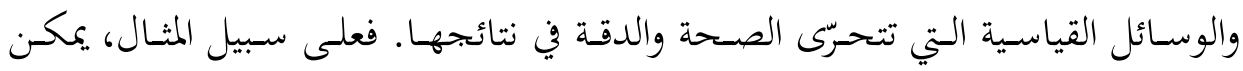




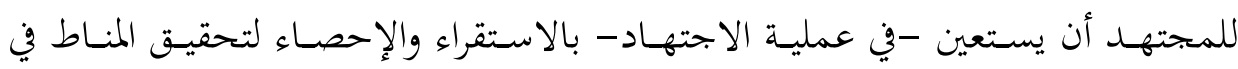

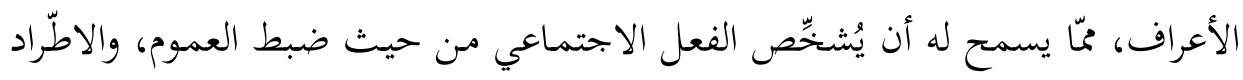

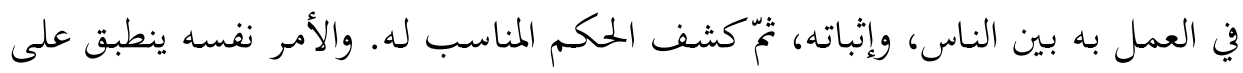

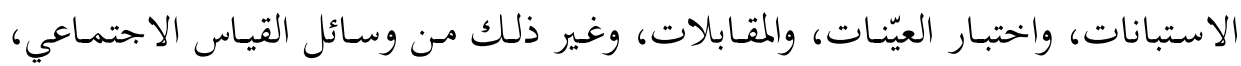

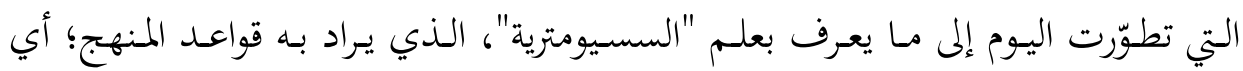

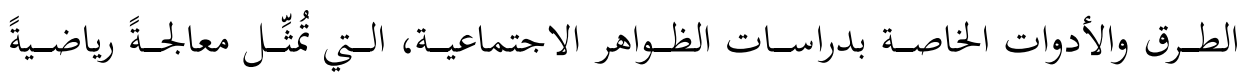

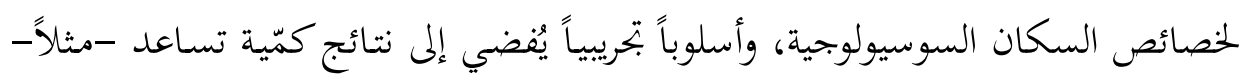

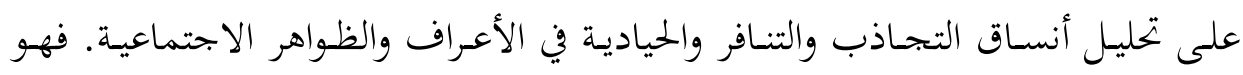

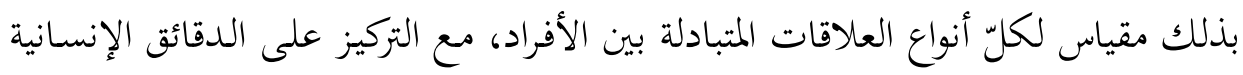

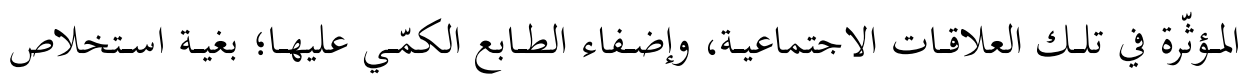

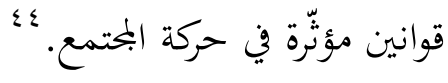
وكان المجتهدون القدامى من العلمـاء قد بيّنوا أهمية الاطلاع على المعارف والعلوم

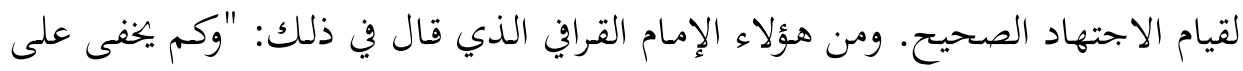

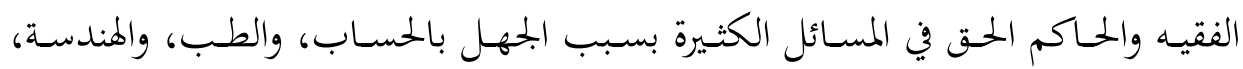

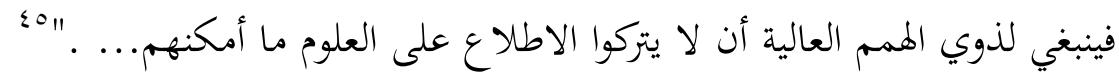

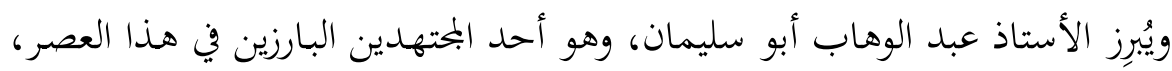

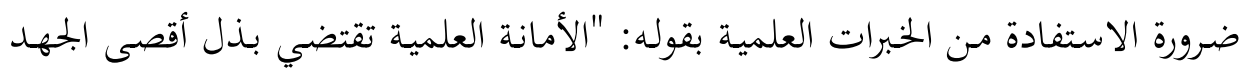

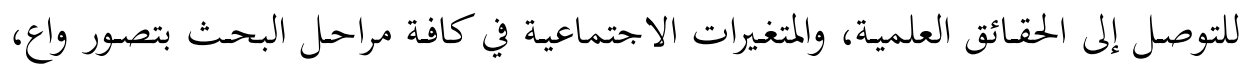

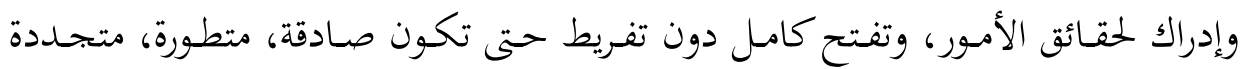

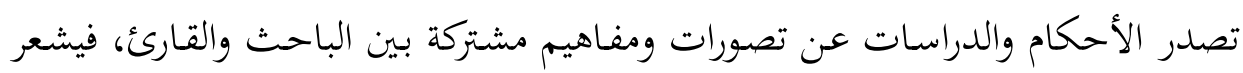

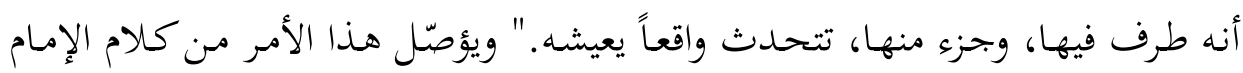

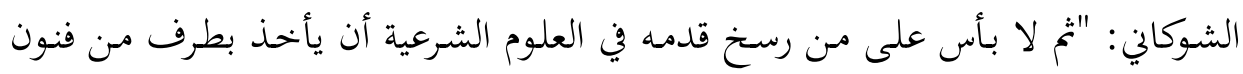

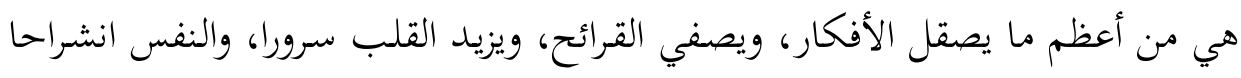
${ }^{44}$ J.L. Moreno, et.al., The Sociometry reader, ed, 1960, pp.127-128.

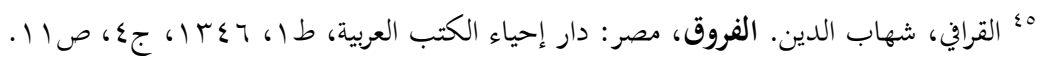




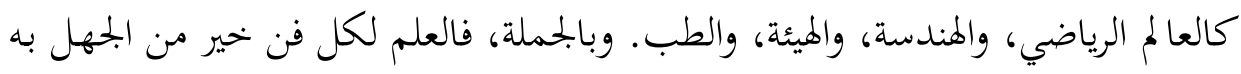

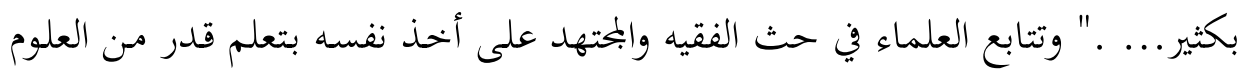

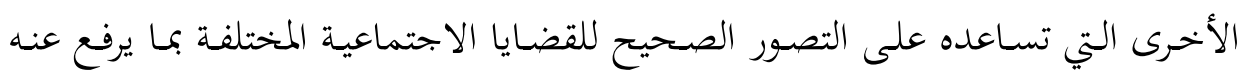

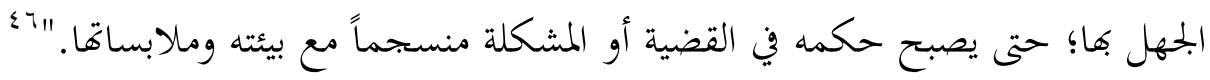
وفيما يخص أهمية المعارف المعاصرة في ضبط مصالح الحياة المتمثّلة في أنشطة الأفراد

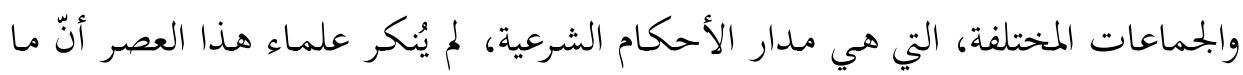

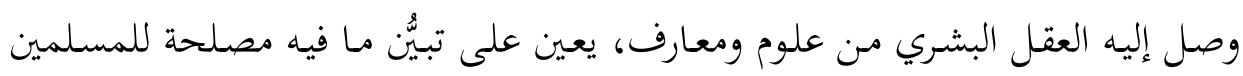

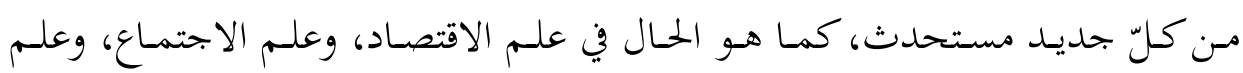

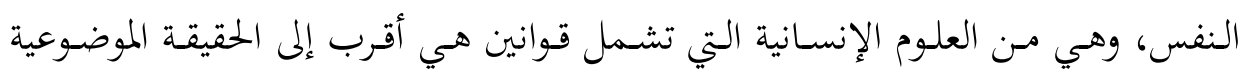

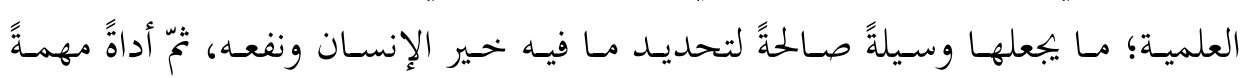

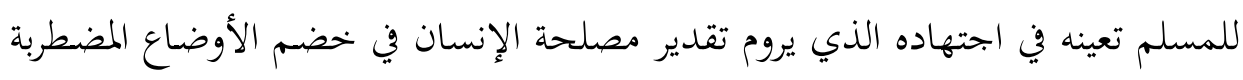

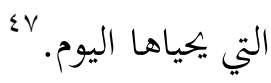

إنّ الاعتمـاد على الملاحظة البسيطة، وربط الأسباب بمسبّباتها لتحديد الأعراف

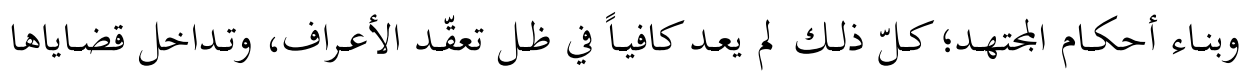

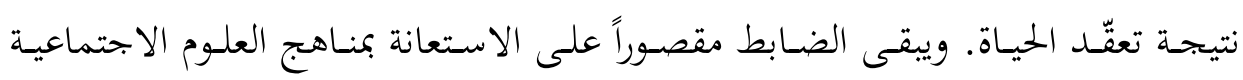

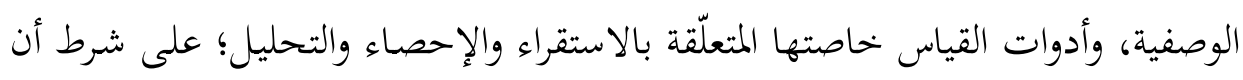
لا تصادم النتائج ثوابت الشريعة.

وهذا ما يحرص الدكتور عبد المجيد النجار على اعتباره في ضبط عملية الاستفادة من

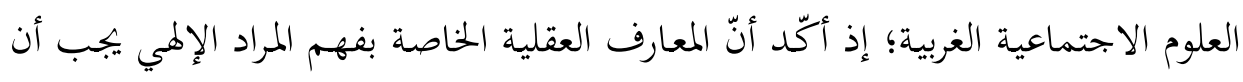

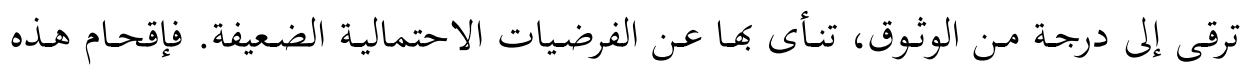

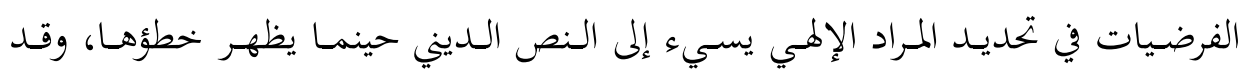

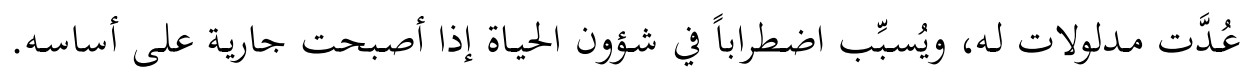

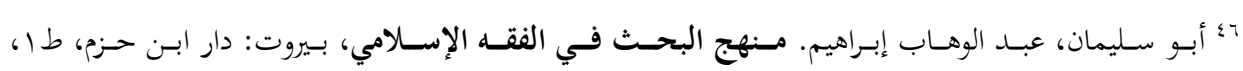

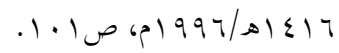

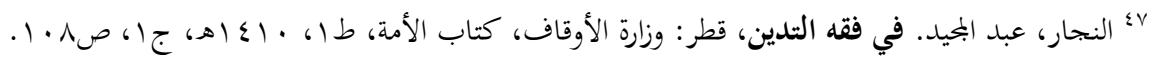


لذا، يجـب الاقتصـاد في استعمال المعارف العقليـة لفهم الدين، وتحرّي إصابة الحـق قدر

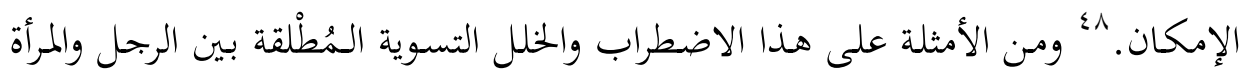
التي يُروّج لها علم الاجتماع المعاصر، والتي تُحتِّم على الرجل والمرأة أن يعملا معاً في بحال

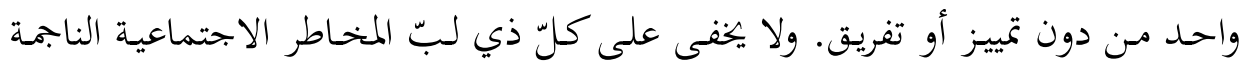
عن ذلك، مثل: الانشغال عن تربية الأطفال، وحرمان الكبار والمسنين من ولن رعاية الأبناء والأقرباء.

\section{خامساً: سنن التغيّر الاجتماعي في ضوء العرف الأصولي}

قد تختلف مسمّيات المدلول الواحد باختلاف فنون المعارف التي تتناوله. فما يعرف

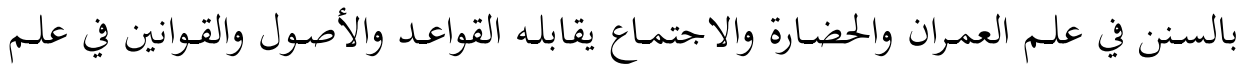

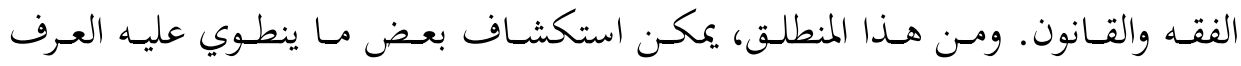

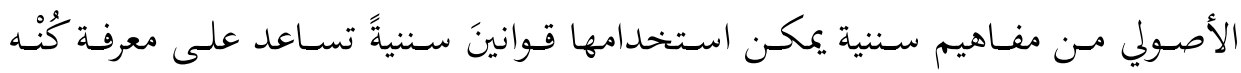

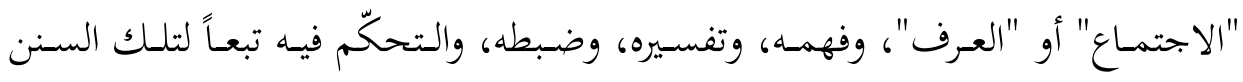
والقوانين الاجتماعية المكنونة فيه. وفيما يأتي بيان لتلك السنن، وما فيها من تداخل:

أ. العرف الأصولي وسنّة الاجتماع في أبعادها المقاصدية:

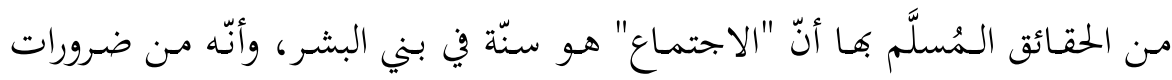

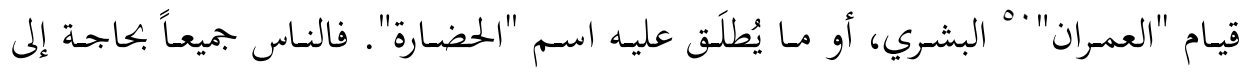

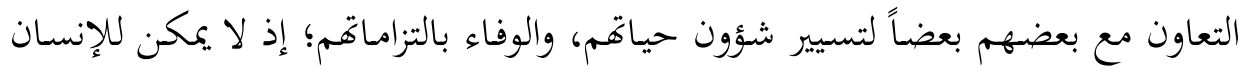

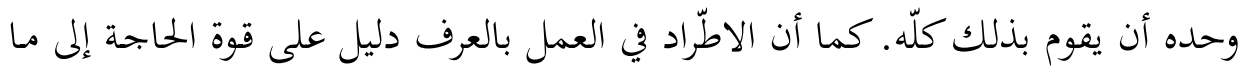

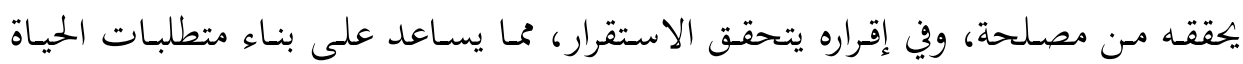

وتنميتها. 
ولا يخفـي هـذا البُعْد السـنني في تأصسيل العلمـاء للعـرف الأصسولي؛ ذلك أنّ تكـرار الفعل "محل العرف" تألفه الأعصاب والأعضاء، خاصةً إذا اقتضته الحاجة الاجتماعية،

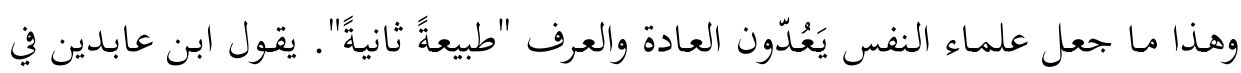

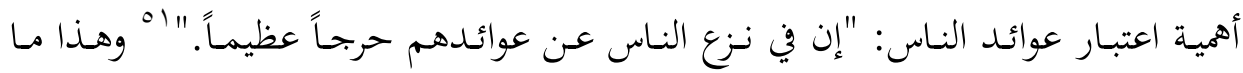
جعله مصدراً للتشريع في الشرائع السماوية والوضعية. يُمتِّل العرف الأصولي "أداةً أصسوليةً" تعمل على مراقبة أحوال الفعل الاجتماعي في

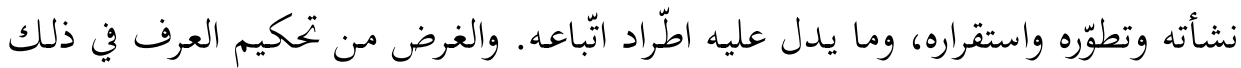

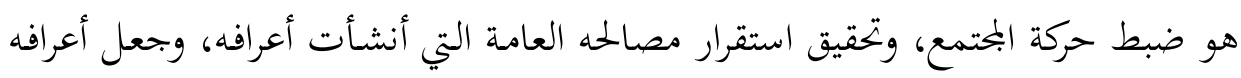

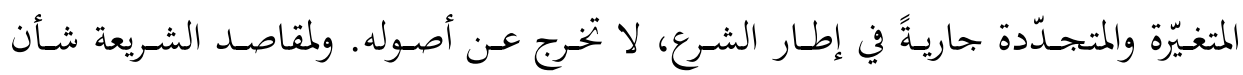

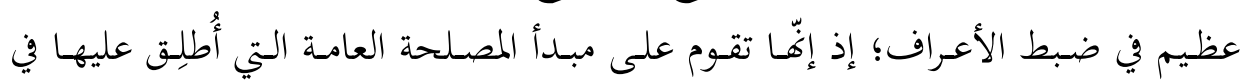
سـياق العرف "الحاجـة" العامـة. ولا يخفى دور مقاصـد الشـريعة في ضـبط نـوع المصـالح

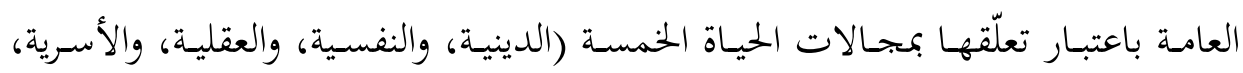

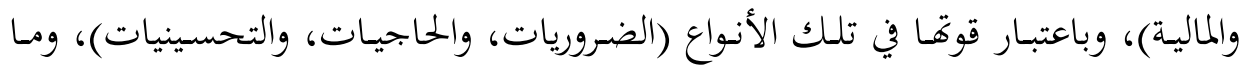
يلحق بتلك الأنواع والمراتب من قواعد وضوابط. ولمك.

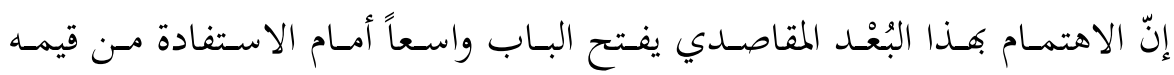
(الشمول، والعدل، والسماحة، واليسر) في تقييم الأعراف، وتوجيه الحكم على المستجد

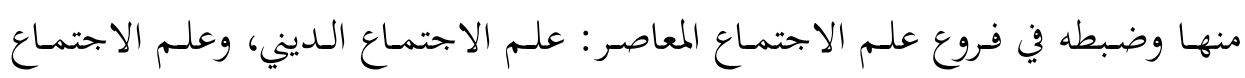

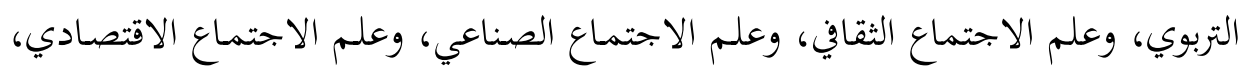

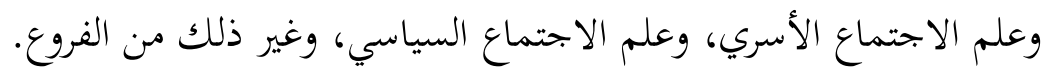

والعرف الأصـولي يمُنِّل أداةً شـرعيةً اجتماعيـةً لتقرير الأعـراف وضـبطها مـن حيـث

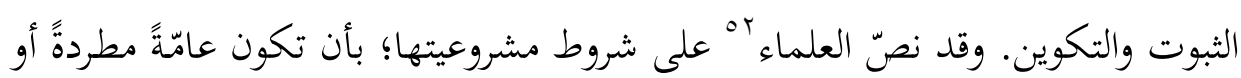

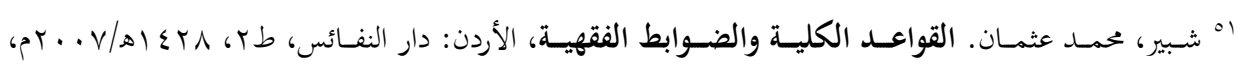


غالبةً، فبإذا اضطربت فلا عبرة بها، وأن تكون حاضرةً لحظة التصرّف، ولا عبرة بالعرف

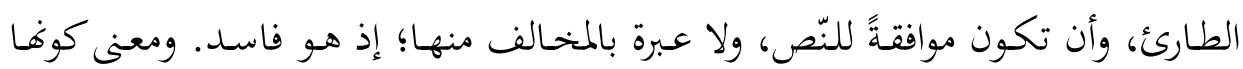
موافقةً أن لا تخالف أصول الشريعة ومقاصدها.

\section{ب. العرف الأصولي وسنّة الفطرة:}

يُعَدّ العـرف مظهـراً مـن مظـاهر مراعـاة "الفطرة"؛ أي الحنلقـة التي بتمـع بـين مكوّن "المادة" و "الروح" في الإنسان، وتُمُثّل "النظام" الذي أودعه الله تعالى في كلّ مخلوق. فنطرة

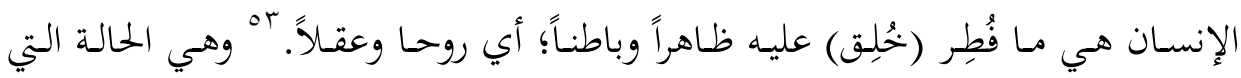

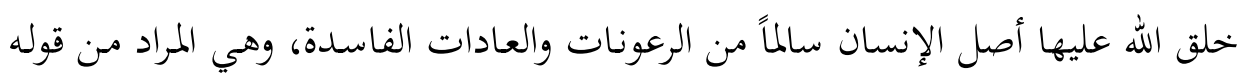

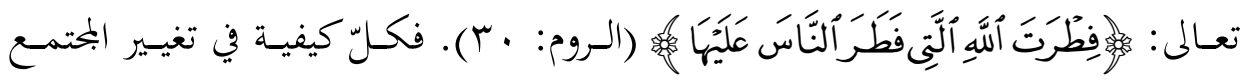
يجب أن تحترم "الفطرة" في سلامتها. قال ابن عاشور: "نحن إذا أجددنا النظر في المقصد

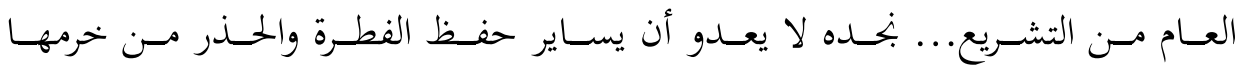

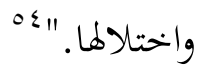

ولا شكّ في أنّ الشريعة الإسلامية هي شريعة الفطرة السوية؛ أي إنّ النفوس تتلقاها

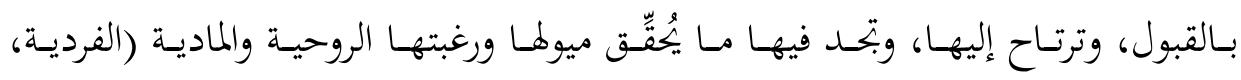

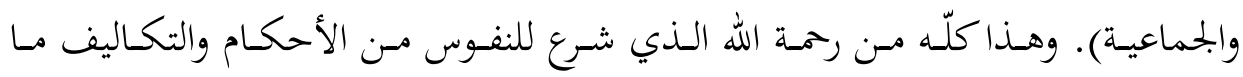
يناسب فطرةجا السوية، وأحوالها القويمة، وأوضاعها السليمة.

إنّ النفوس تميل إلى البناء والإنتاج، وترتاح إلى الإصـلاح والصـلاح، وتكره الفسـاد، وتبغض المفسدين. وكذلك فطرة البشر؛ فهي تريد الخير، وتسعى إلى إثراء النتاج الثنافي إلي

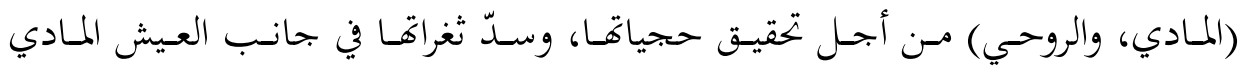
والاقتصادي، وكذا الحياة العقلية والنفسية. قال ابن عاشور: "فالأصول الفطرية هي التي

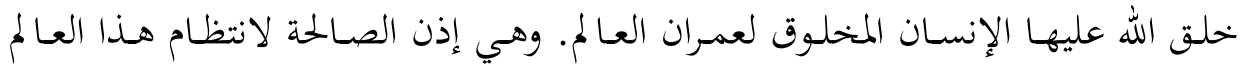

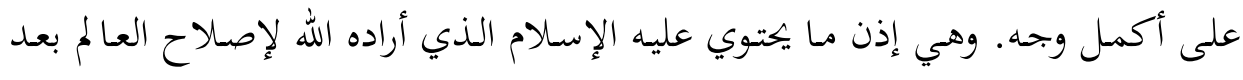
ro ابن عاشور، مقاصد الشريعة الإسلامية، مرجع سابق، صمهـ.

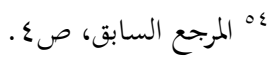


اختلاله." وقال أيضاً: "والحضارة الحق من الفطرة؛ لأغها من آثار حركة العقل الذي هو

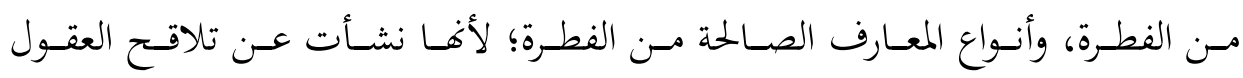

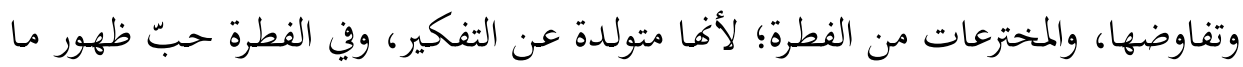

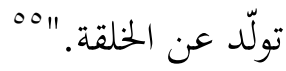

\section{ت. العرف الأصولي وسنّة التغيّر الاجتماعي:}

يُمثِّل العرف الأصـولي في بعض وظائفهـ أداةً لضبط تغيّر أحوالهه في واقعـة مـن حيـاة الناس. فكثير من الأعراف قابلة للتغيير تبعاً لتغيّر المصالح، وتغيّر الحال والزمان والمكان. وتأسيساً على ذلك، قرّر علمـاء التشريع قاعـدة "لا ينكـر تغيّر الأحكام بتغيّر الأزمنـة والأمكنة والأحوال"، وذلك تماشياً مع ما تقتضيه مرونة الشريعة الإسلامية وواقعيتها، وما يناسب فطرة الإنسان التي راعاها الشارع في تشريع ما يناسب قدراها من التكاليف. يُمَّّل العرف الأصولي أيضاً أداةً لإلغاء ما يفسد من الأعراف، وتقرير الصالح مُّا ينشأ

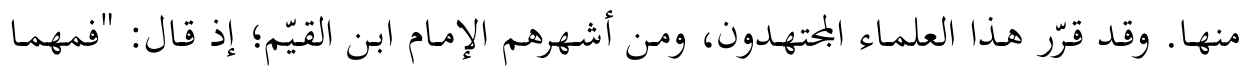
تجدد العرف فاعتبره، ومهما سقط فألغه، ولا تحمد على المنقول في الكتب طول عمرك،

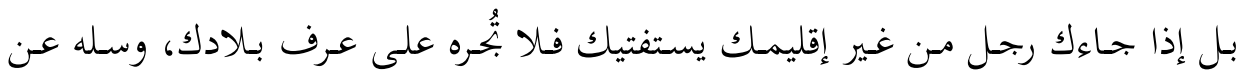
عرف بلده فأجره عليه، وأفته بـه، دون عرف بلدك، والمذكور في كتابك، قالوا فهذا هو الحق الواضح، والجمود على المنقولات ضالال في الدين، وجهل بمقاصد علماء المسلمين،

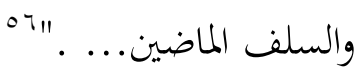

\section{ث. العرف الأصولي وسنّة التدرّج في التغيير:}

نبّه الشيخ محمد الخضري على مسألة تغيّر العادات، ورأى أنّ العادة تتحكّم كثيراً في

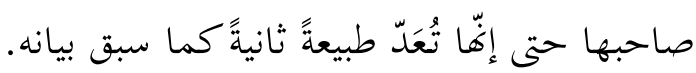

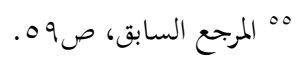

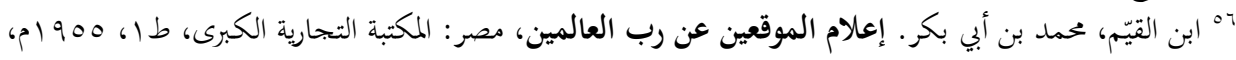




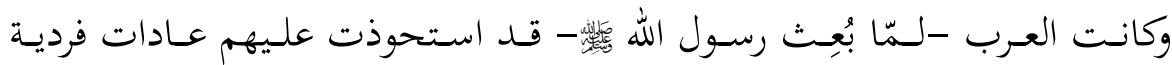

وجماعية وفكرية واجتماعية، فاقتضت الحكمة التشريعية أن يتدرّج معهم المُشرّّع الحكيم

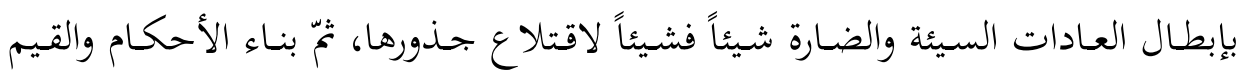
الإسلامية مكاها.

أخذ العرف الأصولي -بوصفه أداةً لإصلاح أحوال الناس وتحقيق مصالحهم- بسنّة

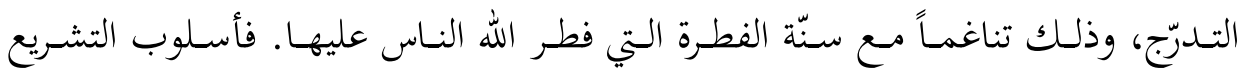
يتناسـب مـع مـا فُطِـرت عليـه الأنفـس السـليمة والعقـول الراجحــة في تقبّل الأخبـار

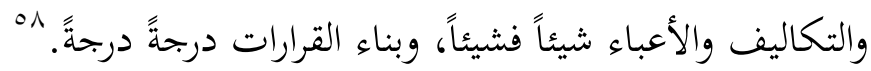

ساعد التدرّج في التشريع الإسلامي على تقبّل هذا التشريع؛ لأنّ النفوس الجحامحة لا

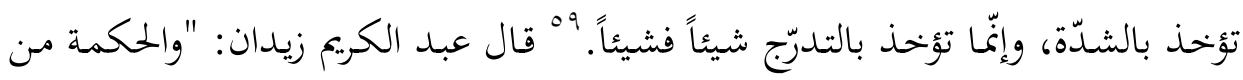

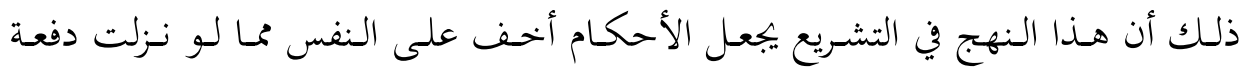

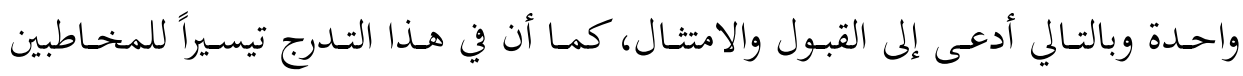

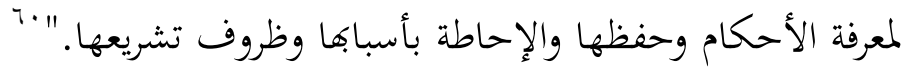
ومن شواهد التدرّج في التشريع: نزول القرآن منجّماً، وعلى مراحل زمنية ومكانية،

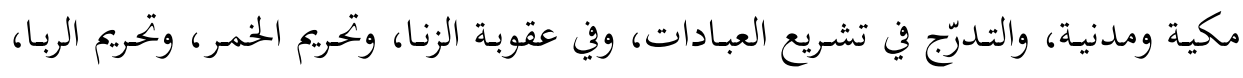
وفرض الجهاد، وغير ذلك من الأمثلة المبسوطة في مُدوّنات تاريخ التشريع.

\section{سادساً: تطبيقات العرف ووسائل التغيّر الاجتماعي المعاصر}

ثمّة أسباب عديدة ذكر علماء الاجتماع أفّا تُسهِم بقدر كبير في تغيّر المجتمعات، بما

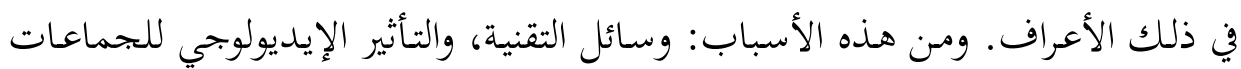

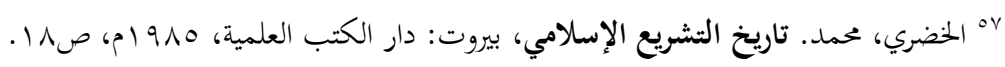

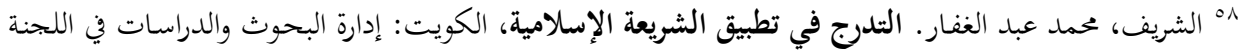

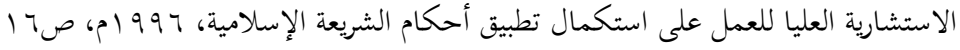

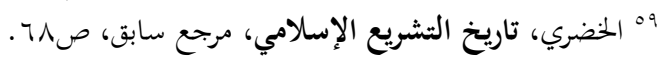

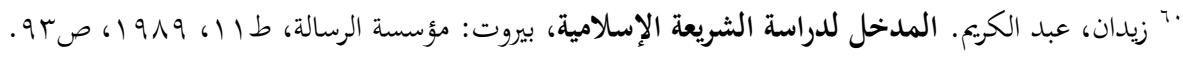




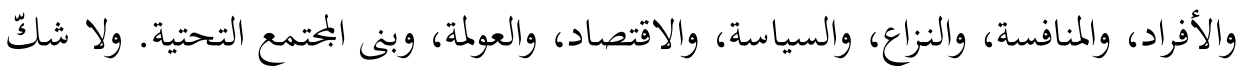

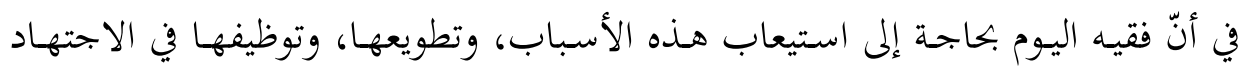

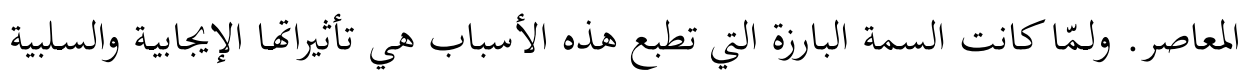

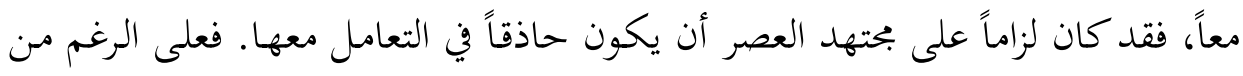

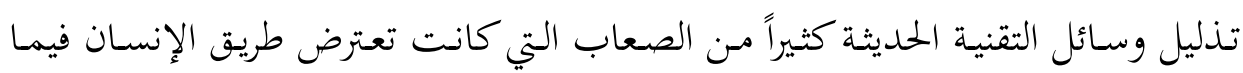

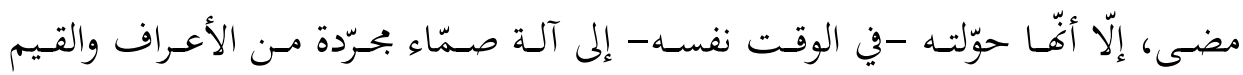

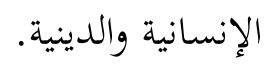

والأمر نفسه ينطبق على الإيديولوجيا التي أسهمت بفاعلية في تحقيق المثل العليا

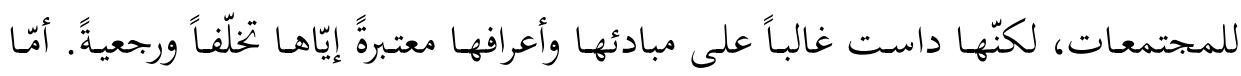

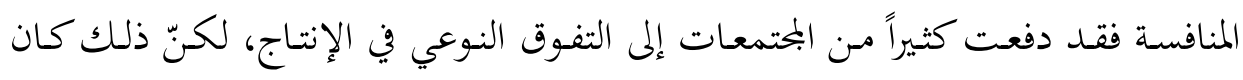

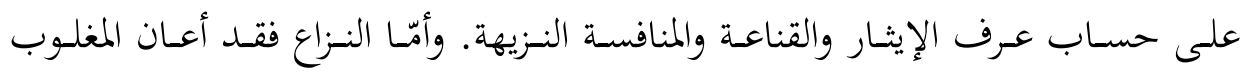

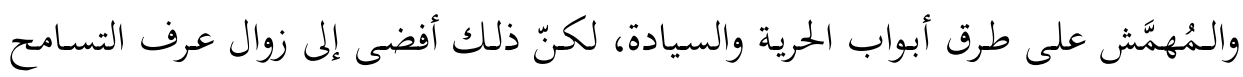

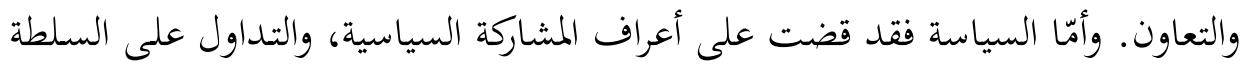

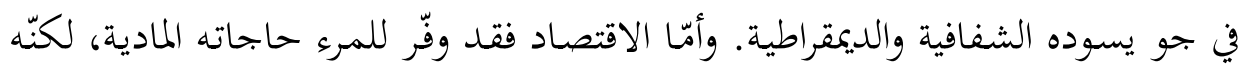
أدّى إلى اختفاء كثير من القيم الروحية في العديد من البلدان المحافظة.

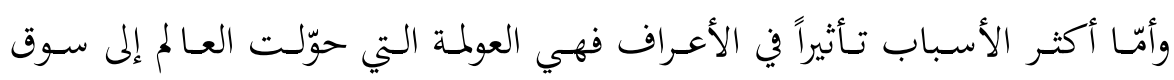

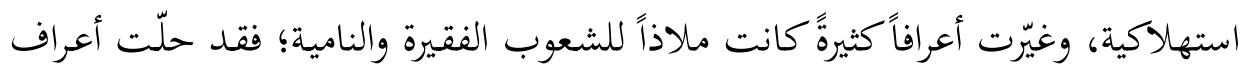

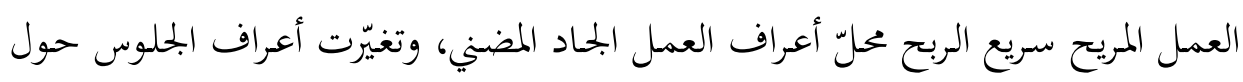

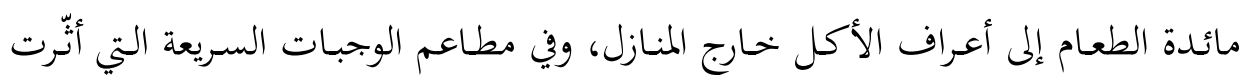

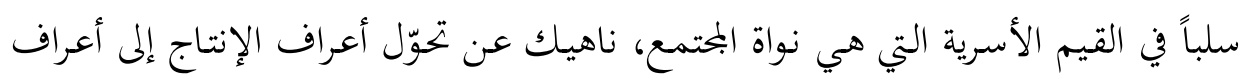

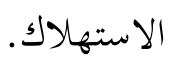

وهذا الحكم ينسحب على الثقافات الوافدة التي أصبحت مثل الرياح العاتية التي

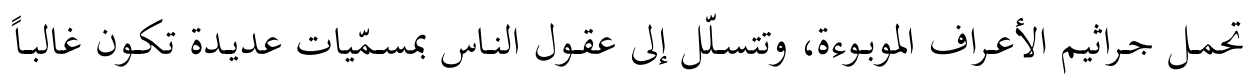

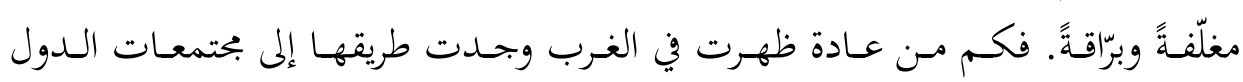




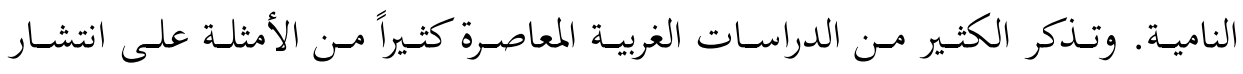
الثقافات بين المجتمعات مثل لباس الزفاف الأبيض الغربي الفاضح الذي لقي التئي استحساناً

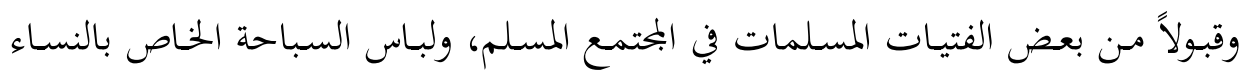

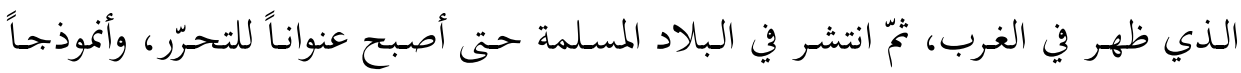

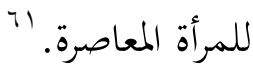

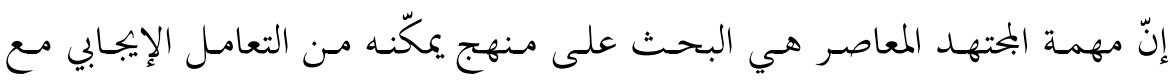

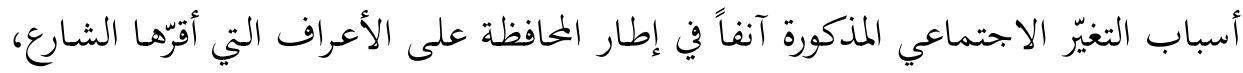

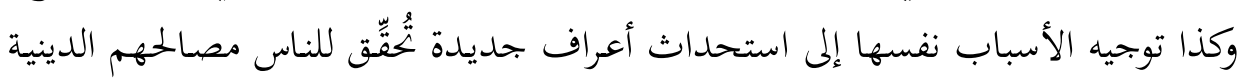

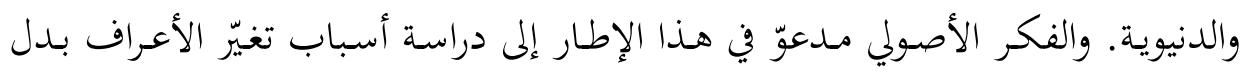

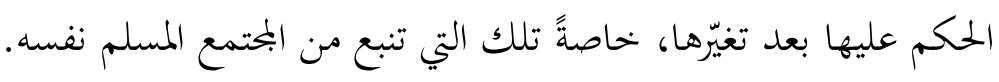
ويتعيّن على المجتهد المعاصر أن يكون على درجة عالية من الحساسية؛ لأنّ أسباب

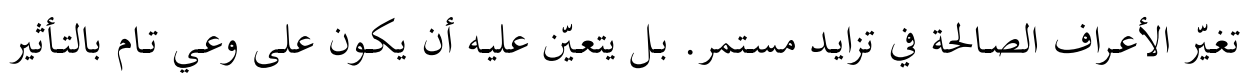

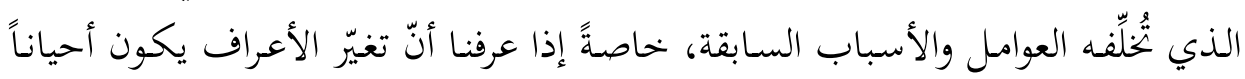

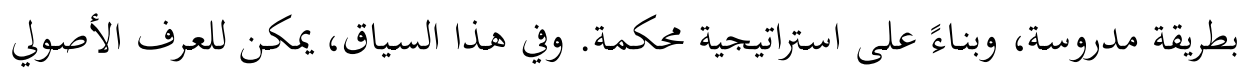

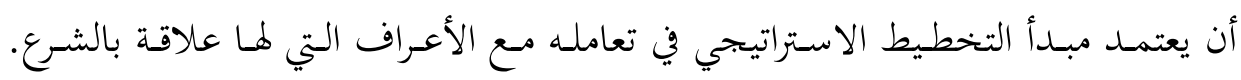

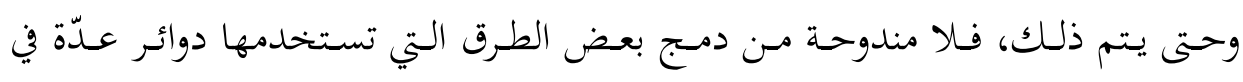

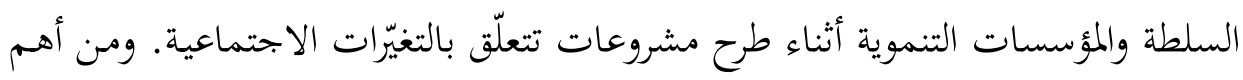

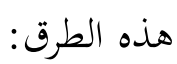

\section{أ. الجهات المُغيَّةرة والمُفيِّرة ووسائل التغيّر الاجتماعي:}

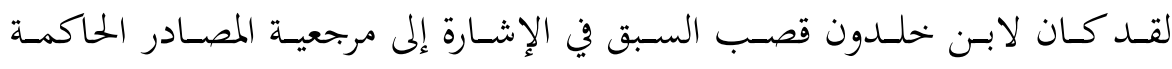

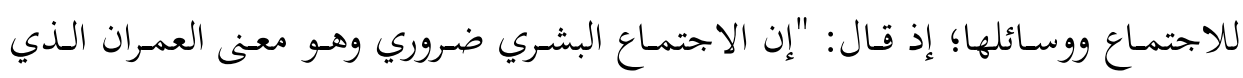

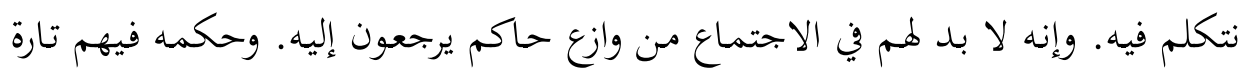

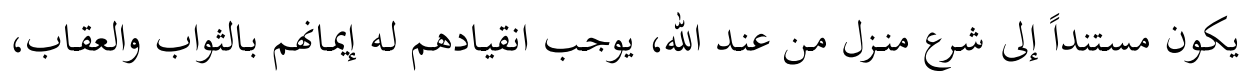

${ }^{61}$ Steven Vago. Social Change, $5^{\text {th }}$ edition. New Jersey: Prentice Hall, 2004, pp.11-37. 
وتـارة إلى سياسـة عقليـة يوجـب انقيـادهم لهـا مـا يتوقعون مـن ثـواب ذلك بعـد معرفتـه

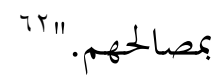

وبلغة العصر، فإنّا نسقط من نظرية ابن خلدون مـا يتعلّق بـالتغيّر الاجتماعي مـن

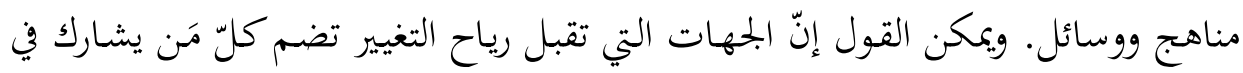

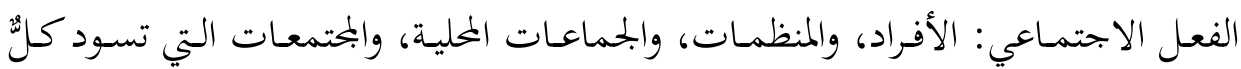
منها أعراف خاصة ترتبط بمجال نشاطها الخاص (أعراف اقتصادية، أو أسرية، أو تربوية؛

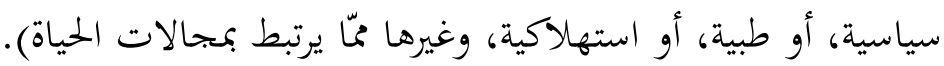

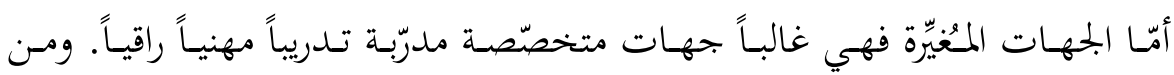
أمثلتها: المحالس التشريعية للقوانين، ومراكز البحوث الاجتماعية على اختلاف فروهيل فروعها.

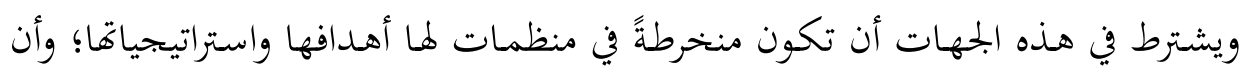

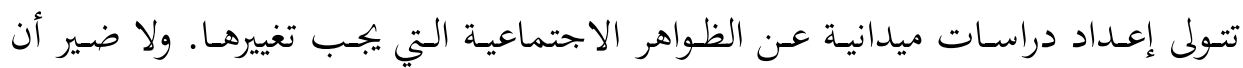

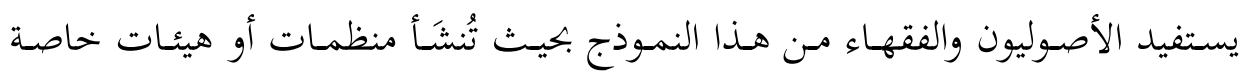

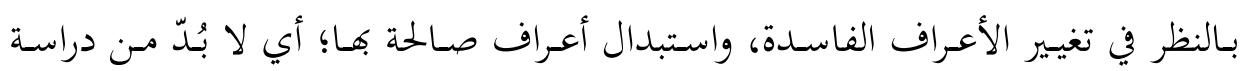
الظواهر الاجتماعية التي تُمثّل إشكالات في بحالها مـن حيث تعرّف أسبابها للحدد منها،

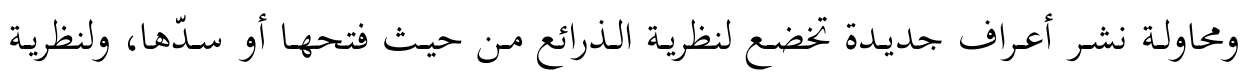

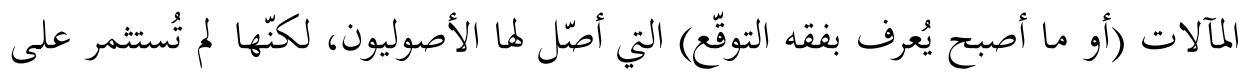
النحو المطلوب.

\section{ب. منهج التغيير ووسائله:}

تعتمــ مؤسسـات التغيسير الرسميـة على منـاهج، أهمهـا: إعـادة التثقيـف، والإقنـاع،

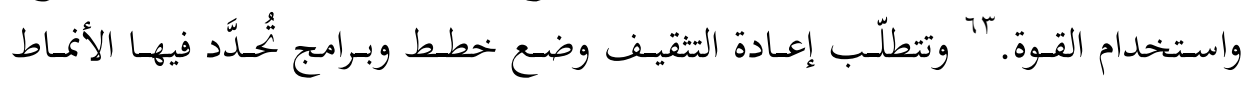

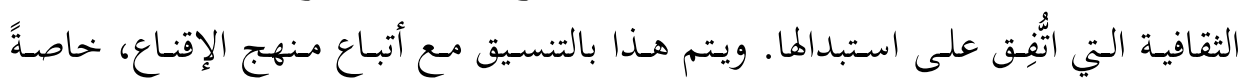

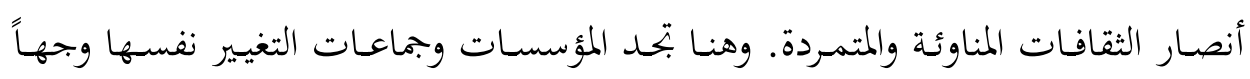

${ }^{63}$ Steven Vago. Social Change, p.393. 
لوجه مع صراع ثقافي داخلي يتطلّب كثيراً من الحذر، وإلّا انقلبت الصورة ليتحوّل المُّغيّر إلى مُغيَّر، في حال لمُ تُدرَس طبيعة الثقافة والعرف الذي يراد تغييره.

وفي هـذا السـياق، يتعـيّن على الأصـولي أن ينظـر إلى الأعــاف المـراد تغييرهـا بهـــا

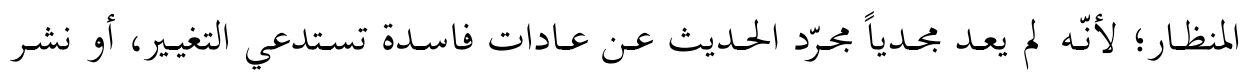
عرف جديد يرجى منه النفع والصالح. فقد قامت حركات تحرّرية تحمل شعاراتٍ مختلفةً

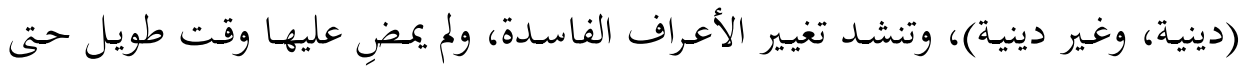

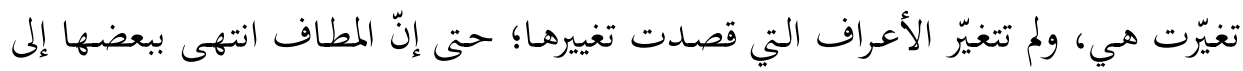

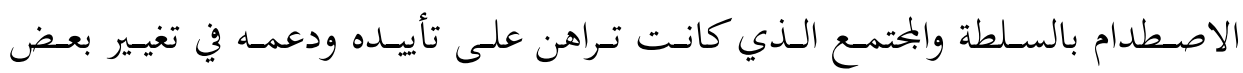
الأعراف الفاسدة. وسبب ذلك هو فقدان المنهج القائم على الدراسة الاجتماعية لطبيعة

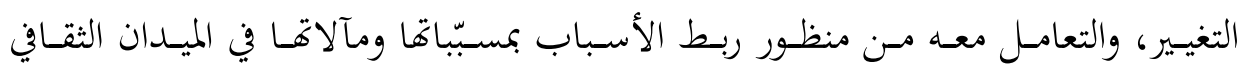
والاجتماعي بمختلف فروعه.

\section{ت. استخدام القانون في تغيير الأعراف والثقافات:}

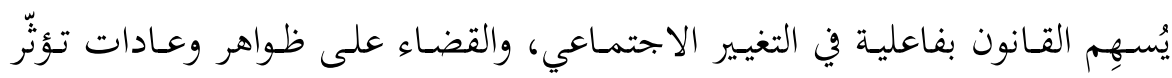

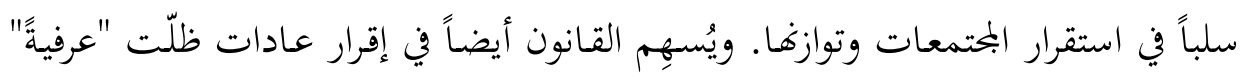

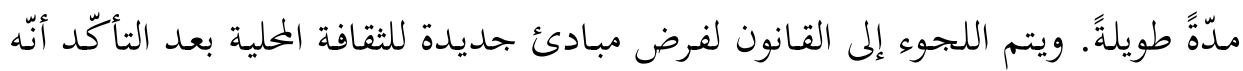

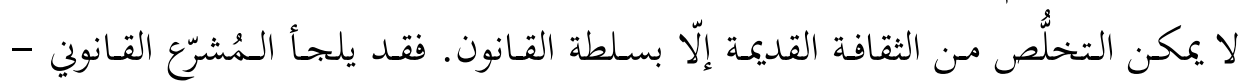

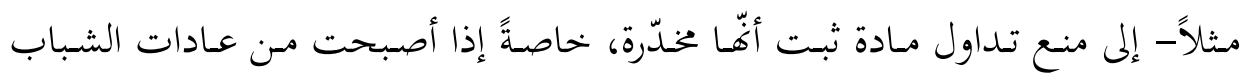
الذين يرتادون النوادي الليلية. ومثال ذلك تحريم كثير مـ القوانين بيع حبوب الإستزي Ecstasy التي تَّوَّل تعاطيها إلى عادة أدمن عليها الشباب في النوادي والمراقص الليلية.

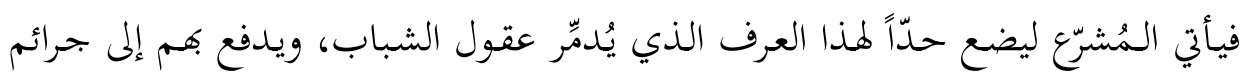
أخرى.

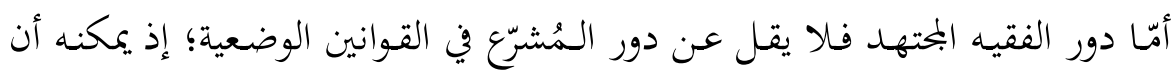
يفتي بتحريم بعض العادات التي تخالف النصوص الشرعية، أو تؤدي إلى مفاسد راجحة.

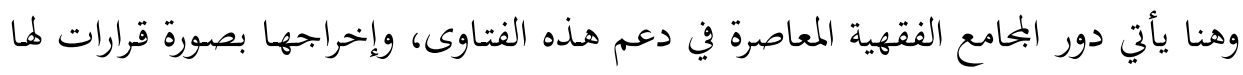




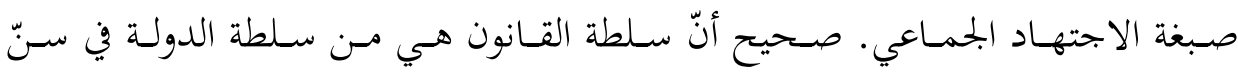

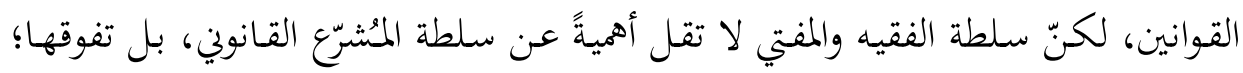

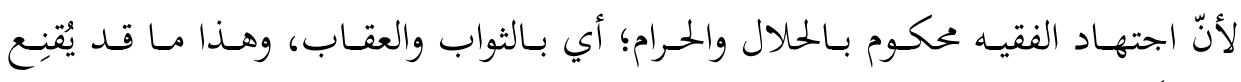

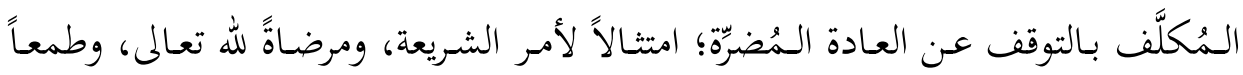

وهذه الوسيلة تتّفق مع منهج الإقناع الذي يتّبعه علماء الاجتماع في تغيير ظاهرة

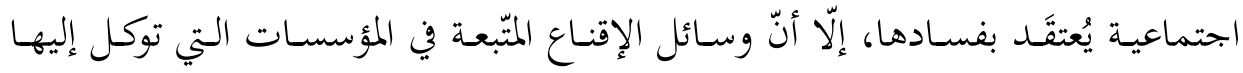

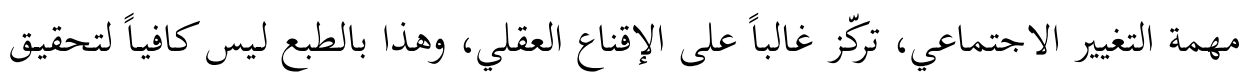

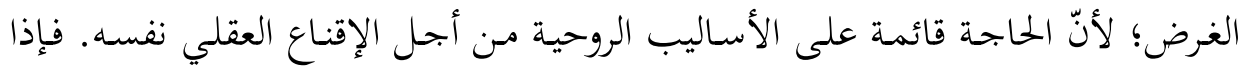

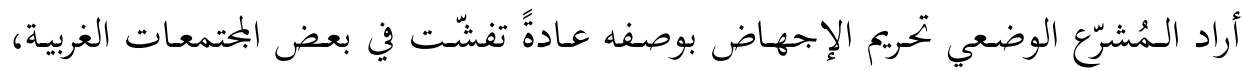

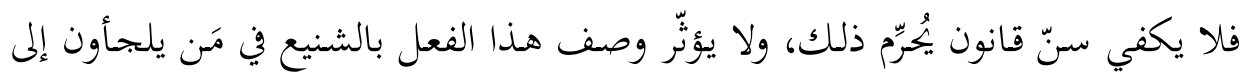

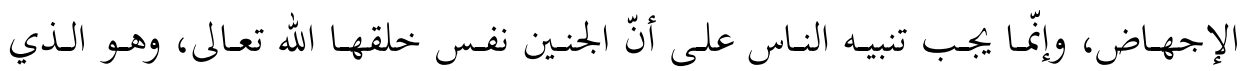

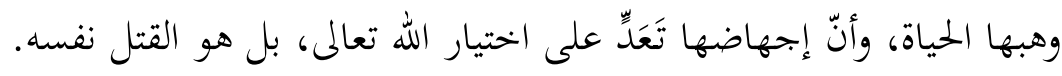

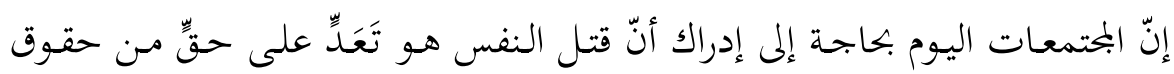

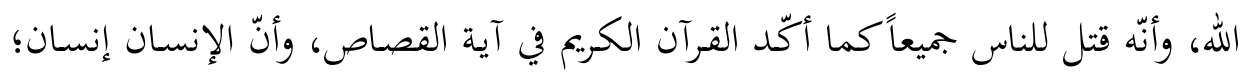

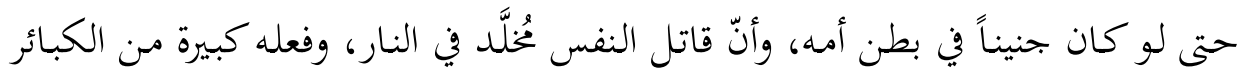

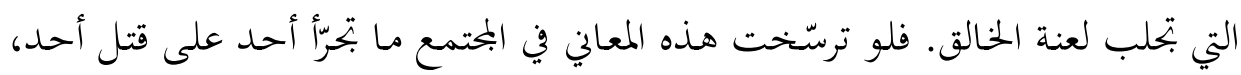

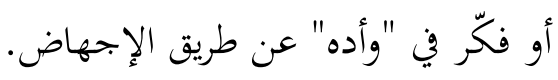

خاتمة:

بيّنـت الدراسـة أنّ العـرف كـان -ولا يزال- محلّ اهتمام فقهاء الشريعة الإسـلامية

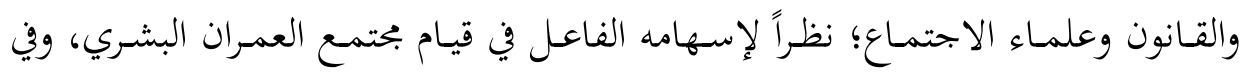

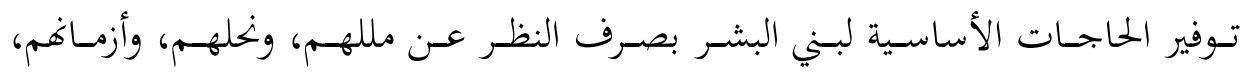


وقد سعت هذه الدراسة إلى بيان جهود العلماء من فقهاء الشريعة والقانون في تقرير أنواع الأعراف وبحالاتما وضوابطها من حيث العموم والاطرّاد وعدم مخالفة الأصول العامة

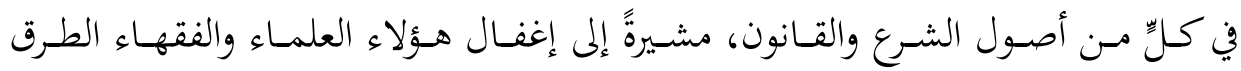
المنهجية اللازمة لقياس درجة العموم والاطراد التي تقوم عليها العلوم الاجتماعية، وعليه

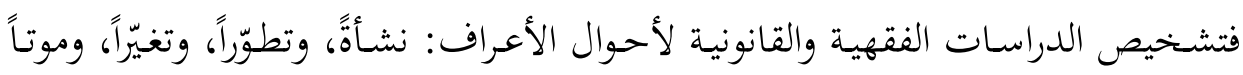
يتطلـب الاستعانة بـأدوات منـاهج العلـوم الاجتماعيـة المعاصـرة، وذلك في مراكـز بكثيـة اجتماعية خاصة بذلك.

وقـد تعرّضـت الدراسـة لجهـود بعض علمـاء الاجتماع الغربي، التي سعت إلى إيجـاد القوانين الخاصة بنشأة الأعراف وتغيّرها وتطوّرها؛ بغية استخدامها والإفادة منها في توجيه المحتمعات والتحكّم فيها؛ محاكاةً لما شهدته العلوم التجريبية من تطوّر في هذا البحال. إلّا

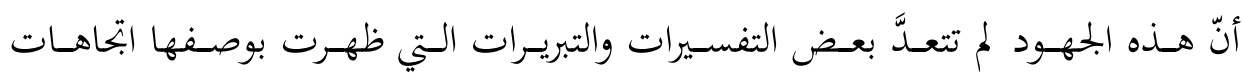
ونظريـات ونـزعات قامـت علسى بحموعـة أفكـار، مثـل: التطـوّر، والنـزاع، والانتشـار، والوظيفية، وغيرها مّّا نوصي بدراسته. وقد أكّد أصحابها وجوب استخدامها قوانينَ في

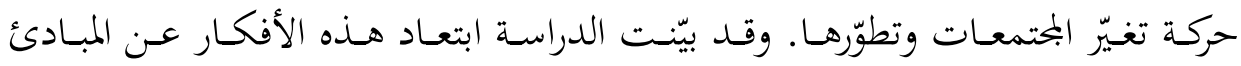

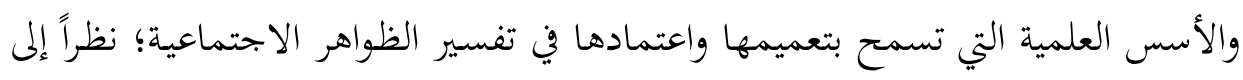
خضـوعها ليمنـة (ذاتيـة) الباحـث الاجتمـاعي، ومصــالحه وأهوائـه الشخصـية وقناعاتـه الفردية حيال القيم الدينية والأخلاقية (المنفلتة، والمتحفّظة)، مُّاّ جعل اعتماد "الموضوعية" أساساً علمياً في تفسيرها وتقدير أحكامها أمراً متعذّراً. وخلصت الدراسة إلى أنّ مقارنة تلك "الأفكار" التي تَظهر مقبولةً في عموم النشاط الاجتمـاعي، لا تتوافق في فلسفتها مـع قيم الواقعيـة في التشريع الإسلامي ومقاصـده في

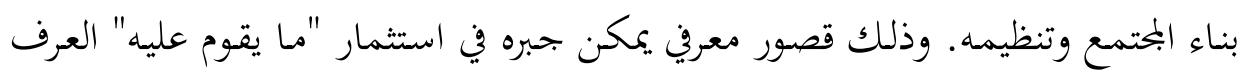

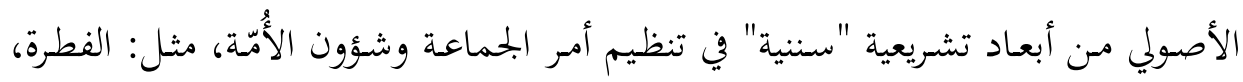
والاجتماع ومقاصده، والتغيّر، والتدرّج. 
إنّ احترام هـذه السنن الاجتماعية واعتمادهـا عن طريق "تفعيل "العرف الأصـولي، من شأنه ضبط نظام الحياة في مختلف بحالاتما، وتلبية حاجات الإنسان، وتوفير الوسائل

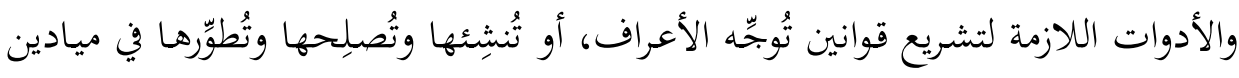
السياسة، والتربية والتعليم، والأسرة، والطب، والاقتصاد...، وكذلك تسخير الجمعيات الدعوية والثقافية للإصلاح والتغيير، والإفادة من وسائل الاتصال والإعلام في نشر ما فيه

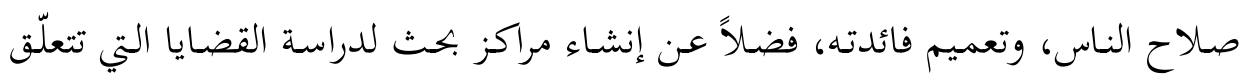

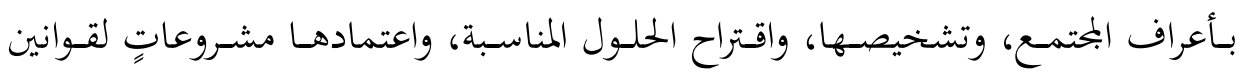

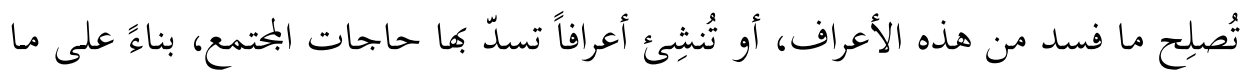

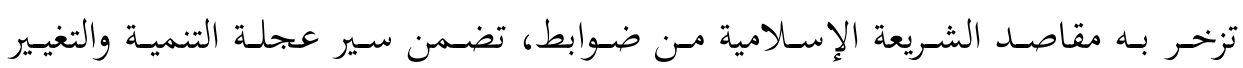

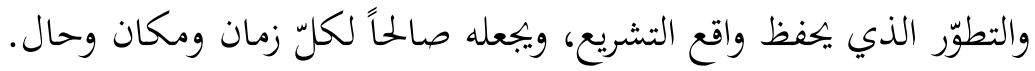

